\title{
Experimental Studies for the VVER-440/213 Bubble Condenser System for Kola NPP at the Integral Test Facility BC V-213
}

\author{
Vladimir N. Blinkov, ${ }^{1}$ Oleg I. Melikhov, ${ }^{1}$ Vladimir I. Melikhov, ${ }^{1}$ Mikhail V. Davydov, ${ }^{1}$ \\ Holger Wolff, ${ }^{2}$ and Siegfried Arndt ${ }^{2}$ \\ ${ }^{1}$ Thermo-Hydraulics Division, Electrogorsk Research and Engineering Center for Safety of Nuclear Power Plants, \\ Saint Constantine Street 6, Electrogorsk, Moscow 142530, Russia \\ ${ }^{2}$ Gesellschaft für Anlagen- und Reaktorsicherheit (GRS) mbH, Kurfürstendamm 200, 10719 Berlin, Germany
}

Correspondence should be addressed to Vladimir I. Melikhov, vladimir.melikhov@erec.ru

Received 3 May 2011; Accepted 19 August 2011

Academic Editor: Alessandro Del Nevo

Copyright (C) 2012 Vladimir N. Blinkov et al. This is an open access article distributed under the Creative Commons Attribution License, which permits unrestricted use, distribution, and reproduction in any medium, provided the original work is properly cited.

In the frame of Tacis Project R2.01/99, which was running from 2003 to 2005, the bubble condenser system of Kola NPP (unit 3 ) was qualified at the integral test facility BC V-213. Three LB LOCA tests, two MSLB tests, and one SB LOCA test were performed. The appropriate test scenarios for BC V-213 test facility, modeling accidents in the Kola NPP unit 3, were determined with pretest calculations. Analysis of test results has shown that calculated initial conditions and test scenarios were properly reproduced in the tests. The detailed posttest analysis of the tests performed at BC V-213 test facility was aimed to validate the COCOSYS code for the calculation of thermohydraulic processes in the hermetic compartments and bubble condenser. After that the validated COCOSYS code was applied to NPP calculations for Kola NPP (unit 3). Results of Tacis R2.01/99 Project confirmed the bubble condenser functionality during large and small break LOCAs and MSLB accidents. Maximum loads were reached in the LB LOCA case. No condensation oscillations were observed.

\section{Introduction}

The VVER-440/213 Pressurized Water Reactors (Russian design) are equipped with a Bubble Condenser Containment (BCC) for the confinement of radioactive releases following design basis accidents [1]. The BCC structure consists of the hermetic compartment system which surrounds the complete primary system and a pressure retaining bubble condenser system comprising a complex pressure-suppression system and air traps, Figure 1. The main function of bubble condenser system is to reduce the pressure of the entire containment in case of a design basis accident, such as a loss of coolant accident (LOCA).

In the case of a postulated large break LOCA, up to a break of 500-mm diameter piping, the steam-air mixture generated within the hermetic compartment system is transferred into the bubble condenser system through the bubble condenser shaft. It penetrates the horizontal spaces between the water trays. The steam-air mixture passes through a large number of vertical openings, the gap/cap inlet openings, to the water trays. These gap/cap inlet openings are lengthy rectangular gaps covered by rectangular caps forcing the steam-air mixture to flow through the water pools, that is, the initial upward directed flow is turned 180 degrees by the caps into a downward oriented flow (see Figure 3). The increasing pressure of the steam-air mixture below the water tray forces the steam-air mixture to move down the water inside the cap around the gap until the lower edge of the cap is reached and the steam-air mixture flows into the water pool in the water tray, distributing the steam/air flow into the water by the zigzag-shaped lower edge of the cap. The steam is condensed by the cold water in the water trays; the residual air leaves the surface of the water pool and is collected within the space above.

The gas volumes above the water levels are connected to large volumes of the air traps by one way check valves, which allow the air to flow into the air trap volumes preventing its backflow. This results in a reduction of the maximum 


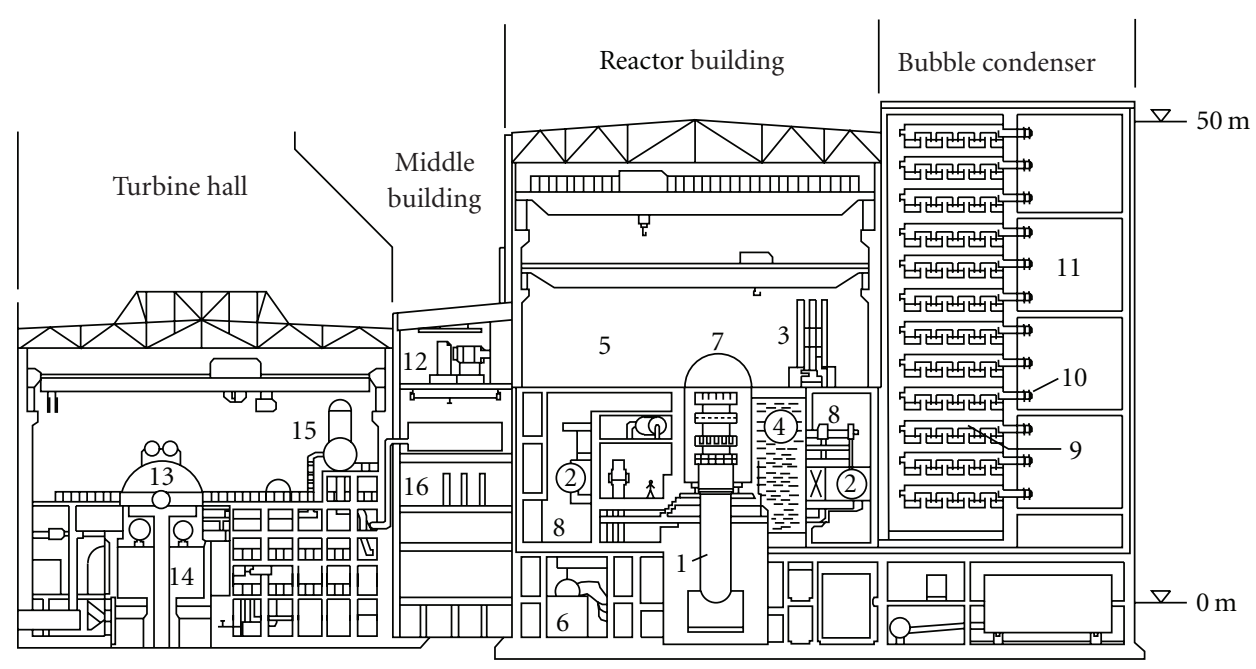
(1) Reactor pressure vessel
(2) Steam generator
(3) Refueling machine
(4) Spent fuel pit
(5) Reactor hall
(6) Make-up feedwater system
(7) Protectice cover
(8) Confinement system
(9) Bubble condenser trays
(10) Check valves
(11) Air traps
(12) Intake air unit
(13) Turbine
(14) Condenser
(15) Feedwater tank with degasifier
(16) Electrical instrumentation and control compartments

Figure 1: VVER-440/213 plant layout.

pressure in the upstream volumes and the hermetic compartment system below atmospheric as soon as the residual steam has been condensed at the corresponding surfaces, by the active spray system and the reverse flow of the bubble condenser (BC) water (so-called passive spray) expected during LB LOCA.

The bubble condenser system was designed to withstand design basis accident conditions and to maintain its integrity in order to fulfill its safety function. Nevertheless, particularly for design basis accidents, detailed analyses identified the need to improve the modeling of accidents and to extend the knowledge of integral and separated effects. There was also a need to produce qualified experimental data in order to strengthen the basis for computer code validation.

During the 1990s, a number of investigations, including analyses and experiments, have been performed in order to ascertain the capabilities of the VVER-440/213 bubble condenser. The large-scale test facility BC V-213 at the Electrogorsk Research and Engineering Center on NPPs Safety (EREC) was developed for experimental investigation of the bubble condenser system of VVER-440/213 in the frame of Tacis/Phare Project PH 2.13/95 [2]. The test facility is an integral model of the NPP's hermetic compartments with full-scale fragment of BC. The BC V-213 test facility is equipped with a system of high pressure vessels and pipelines that makes it possible to simulate both primary and secondary coolant blowdown under conditions analogous to those under NPPs design accidents.
According to the $\mathrm{PH}$ 2.13/95 Project there were performed tests simulating LB LOCA conditions as applied to Paks NPP, Hungary. However, the obtained results may not be used completely to justify the response of Bubble Condenser Containment System at unit 3 of the Kola NPP, since there are two distinctive features in design. They are as follows:

(i) twice the number of DN 500 check valves installed between the $\mathrm{BC}$ and the air traps at Kola NPP against Paks NPP;

(ii) there is only one corridor with an area of $15.7 \mathrm{~m}^{2}$ between steam generator boxes and dead-end volume at Kola NPP.

The specific features mentioned above may exercise a significant influence on the $\mathrm{BC}$ behavior as well as on the variables characterizing its operation. So, specific thermohydraulic experimental qualification of the $\mathrm{BC}$ is required in this case. This was the main objective of the R2.01/99 Project, which was performed in 2003-2005.

Main results obtained in the frame of these tests are described in the paper.

\section{Short Description of the BC V-213 Test Facility}

The test facility is an integral model of the NPP's hermetic compartments built in scale $1: 100$ as regards the volumes 


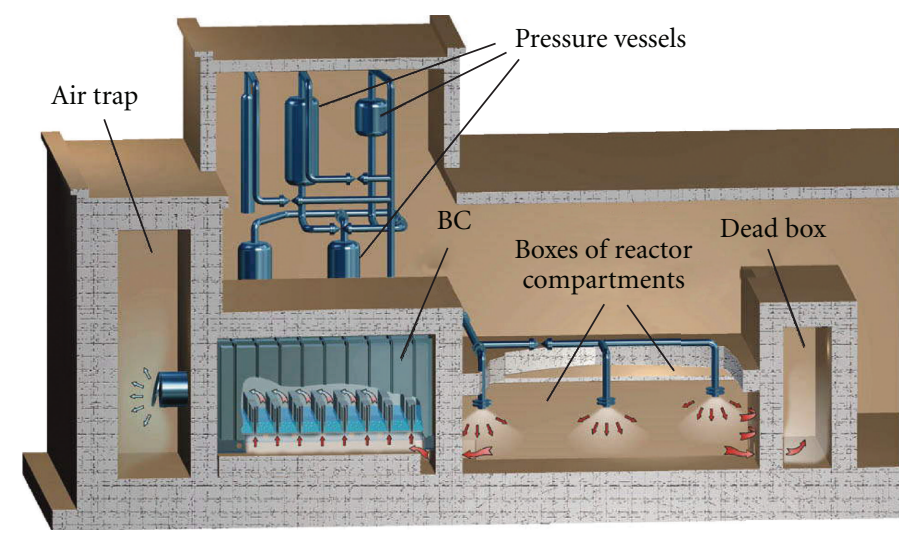

(a) General view of the facility

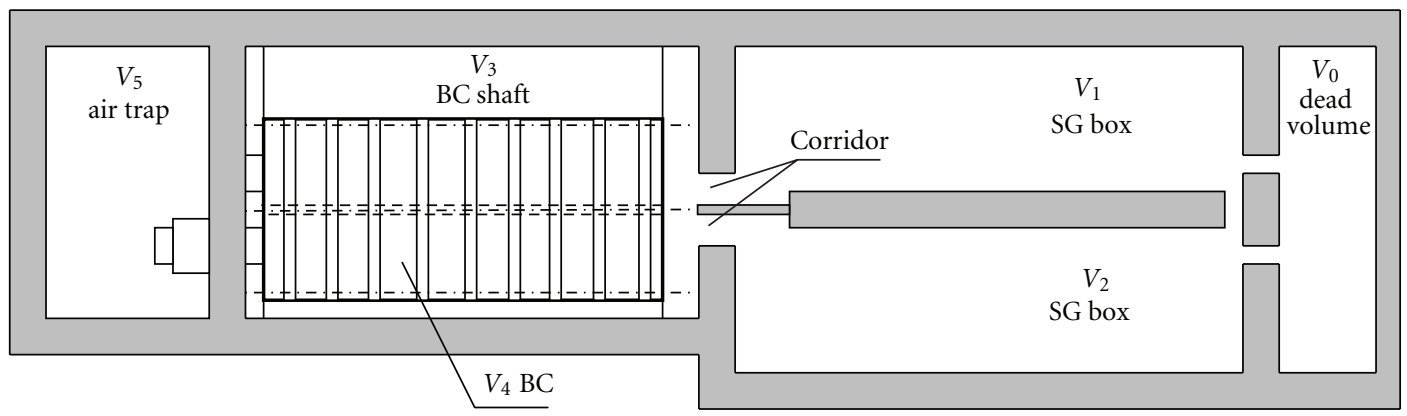

(b) Top view

FIgURE 2: BC V-213 test facility.

and flow areas with full-scale fragment of bubbler condenser, Figures 1 and 2.

Main elements of the BC V-213 test facility are as follows:

(i) five hermetic boxes composed of the dead-end volume $V_{0}$, two steam generators boxes $V_{1}$ and $V_{2}, \mathrm{BC}$ shaft $V_{3}$, and air trap $V_{5}$;

(ii) full-scale fragment of bubbler condenser volume $V_{4}$ located in $V_{3}$ with the relief valve DN250 and two check valves DN173; the $\mathrm{BC}$ fragment consists of two sections with nine gap/cap units each; the tray is filled with nonborated water (initial level $500 \mathrm{~mm}$ ) (Figure 3);

(iii) five high-pressure vessels $V_{v 1}, V_{v 2}, V_{v 3}, V_{v 4}$, and $V_{v 5}$ for preparation of the coolant (water and steam) with predefined parameters (Figure 4);

(iv) additional steam supply pipeline connected to the $V_{v 1}$ pressure vessel;

(v) blowdown lines DN220 with three branches located in the $V_{1}$ box at different distances from corridor to $\mathrm{BC}$ inlet;

(vi) blowdown nozzles and rupture disks installed at the ends of the blowdown lines' branches;

(vii) sprinkler system with two nozzles located in the $V_{1}$ and $V_{2}$ boxes.

The specific features of the test facility with reference to Kola NPP unit 3 are two check valves DN173 and only one
TABLE 1: Geometrical parameters of the hermetic compartments of the test facility.

\begin{tabular}{lccc}
\hline $\begin{array}{l}\text { Hermetic box } \\
\text { (designation) }\end{array}$ & $\begin{array}{c}\text { Volume, } \\
\left(\mathrm{m}^{3}\right)\end{array}$ & $\begin{array}{c}\text { Total area of } \\
\text { walls, }\left(\mathrm{m}^{2}\right)\end{array}$ & $\begin{array}{c}\text { Heat insulated } \\
\text { area, }\left(\mathrm{m}^{2}\right)\end{array}$ \\
\hline Dead volume $\left(V_{0}\right)$ & 46,5 & 98 & 0 \\
Steam generator box $\left(V_{1}\right)$ & 71,8 & 121 & 40 \\
Steam generator box $\left(V_{2}\right)$ & 72,5 & 124 & 41 \\
BC shaft $\left(V_{3}\right)$ & 75 & 200 & 98 \\
BC gasroom $\left(V_{4}\right)$ & 61,1 & 77 & 0 \\
BC water in trays & 12,8 & 73 & 0 \\
Air trap $\left(V_{5}\right)$ & 176,5 & 206 & 93 \\
\hline
\end{tabular}

corridor between $V_{1}$ and $V_{0}$ boxes. The corridor between $V_{2}$ and $V_{0}$ boxes is closed.

Main geometrical parameters of the boxes and highpressure vessels are presented in Tables 1 and 2, correspondingly.

The test facility instrumentation comprises standard and nonstandard instruments, quasistatic measurements with a sampling rate of $10 \mathrm{~Hz}$, and dynamic measurements of sampling rate up to $1000 \mathrm{~Hz}$. The total number of measuring channels, including the major and auxiliary ones is about 300 .

Detailed descriptions of the test facility and its measuring system are presented in $[3,4]$. 


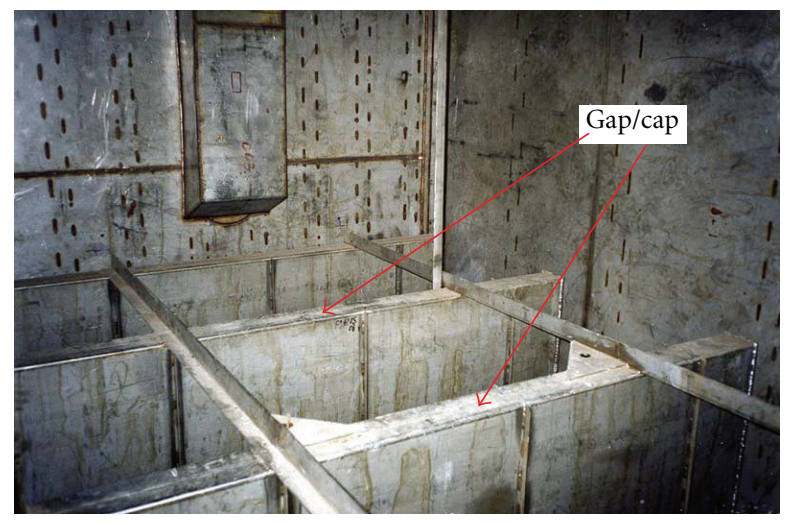

(a) General view of the BC (without water)

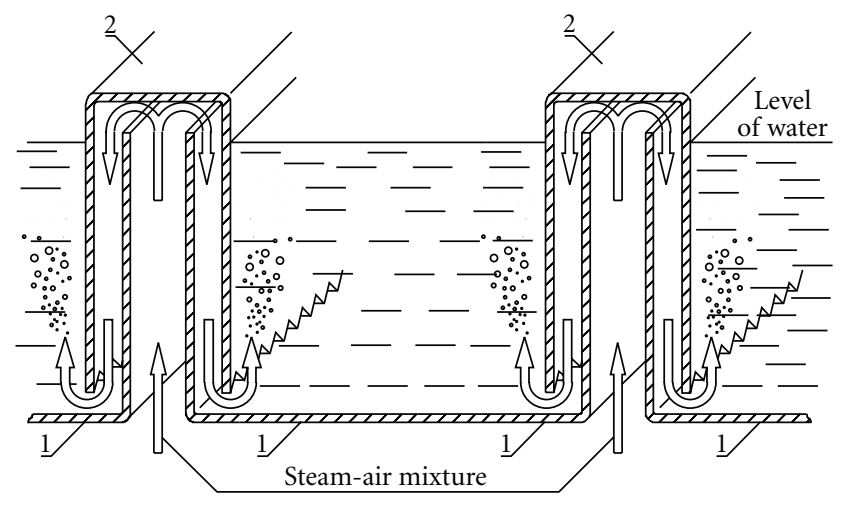

(b) Gap-cap unit: 1 -tray, 2 -cap

FIgURE 3: Gap/cap systems of the BC V-213 test facility.

\section{Test Plan and Methodology of Investigations}

Based on analysis of test matrix developed in the frame of Tacis/Phare PH2.13/95 [5] six tests were specified for investigation of BC system under accident conditions of Kola-3 NPP, Table 3.

General methodology of investigations and the main steps are the following.

(1) Modelling of an accident at Kola NPP with the ATHLET code [6], where the mass flow rate and specific enthalpy of discharged coolant through the break are calculated (so called MER-Mass and Energy release Rate).

(2) Variant calculations of coolant discharge from the high-pressure system of BC V-213 test facility are performed with the same code ATHLET in order to define facility operation conditions (water temperature in the high pressure vessels, nozzle diameter, etc.), allowing to simulate the NPP coolant blowdown parameters reduced by 100 times (in accordance with scale of the test facility). Test scenario is specified on the basis of these ATHLET calculations.

(3) The test is performed in accordance with the specified scenario.
TABLE 2: Geometrical parameters of the high-pressure vessels.

\begin{tabular}{lccc}
\hline Vessel designation & $\begin{array}{c}\text { Volume, } \\
\left(\mathrm{m}^{3}\right)\end{array}$ & $\begin{array}{c}\text { Inner diameter, } \\
(\mathrm{m})\end{array}$ & $\begin{array}{c}\text { Height, } \\
(\mathrm{m})\end{array}$ \\
\hline$V_{v 1}$ & 1.95 & 1,03 & 2,887 \\
$V_{v 2}$ & 1.2 & 1,03 & 1,83 \\
$V_{v 3}$ & 0.91 & 1,0 & 0,73 \\
$V_{v 4}$ & 2.25 & 1,0 & 2,435 \\
$V_{v 5}$ & 0.44 & 0,4 & 4,31 \\
\hline
\end{tabular}

(4) Experimental MER is determined by posttest analysis of the coolant discharge from the high-pressure system of the test facility with the ATHLET code.

(5) Validation of the COCOSYS code [7] on experimental data concerning thermal-hydraulic processes in $\mathrm{BC}$ and hermetic compartments at BC V-213 test facility.

(6) Application of the validated COCOSYS code for analyzing of thermal-hydraulic processes in the hermetic compartments and BC loading during a corresponding accident at Kola NPP.

The detailed investigations of $\mathrm{BC}$ response under $\mathrm{LB}$ LOCA conditions are one of the important aims of the project. The double-ended break of main circulation line (MCL) close to the inlet reactor nozzle with simultaneous total loss of electricity is considered. Nodalization scheme of VVER-440/213 and corresponding ATHLET input deck are prepared. Two loops are used for modeling of one accidental loop and five intact ones, respectively. Pressurizer is connected with the intact loop. Nodalization scheme includes 80 thermofluid objects consisted of 294 control volumes and 219 junctions. Heat conduction objects are divided into 186 control volumes with 756 cells. For calculation of core power the point reactor kinetics model is used. Initial conditions for the LB LOCA accident are presented in Table 4.

Leak opening time is $0.01 \mathrm{~s}$. Table 5 presents sequence of main events and timing during LB LOCA.

The scram signal due to decreasing of pressure in the primary circuit is switched on at $0.03 \mathrm{~s}$ and core power is decreased. Coolant is mainly discharged from pressure vessel side, because of coolant supply from cold legs of intact loops. The pressure in the primary circuit is sharply decreased down to saturation pressure $(\approx 8 \mathrm{MPa})$, the pressure in the pressurizer is slower decreased due to saturation conditions in the pressurizer at the initial moment. The pressurizer is emptied at $15 \mathrm{~s}$. The vapor in the core is raised very quickly due to reverse of direction of coolant flow. In the upper plenum vapor is appeared earlier than in the lower plenum. Hydroaccumulators start supplying the coolant to the reactor vessel at $5.4 \mathrm{~s}$. Total mass of the coolant in the primary circuit is more or less stabilized after $\approx 20 \mathrm{~s}$. The cooling of the core is secured due to supply of the coolant from hydroaccumulators. The maximum flow rate of discharged coolant through the break $\sim 18000 \mathrm{~kg} / \mathrm{s}$ is achieved at the initial moment, after that mass flow rate decreases down to $\sim 6000 \mathrm{~kg} / \mathrm{s}$ at $10 \mathrm{~s}$ and later on to about $2000 \mathrm{~kg} / \mathrm{s}$ at $25 \mathrm{~s}$ 


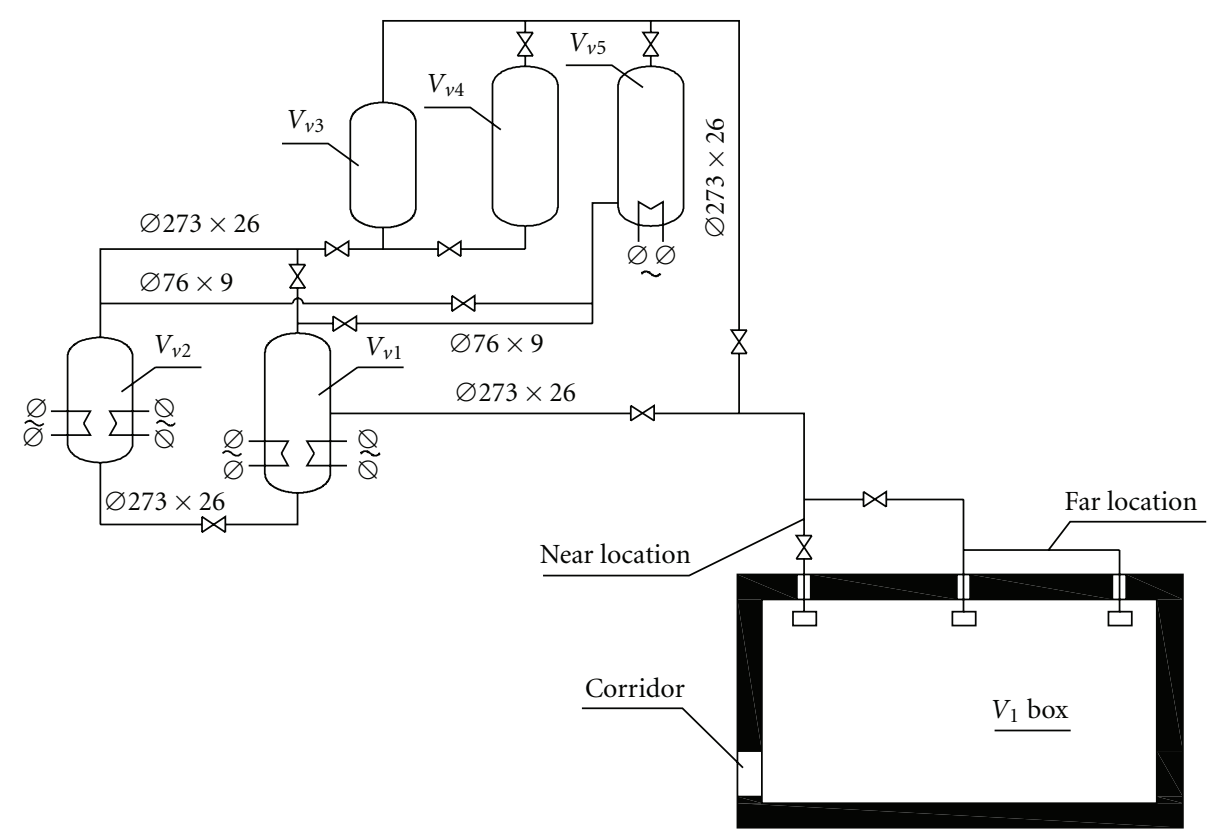

FIGURE 4: High-pressure system.

TABLE 3: Test plan.

\begin{tabular}{lcc}
\hline Test designation (according to [5]) & Accident & Test purpose \\
\hline Test 1 & LB LOCA & Integral behavior of the compartment and bubble condenser system \\
Test 4 & LB LOCA & Response of bubble condenser system to maximum steam loading \\
Test 5 & LB LOCA & Response of bubble condenser system to maximum air loading \\
Test 7 & MSLB & Response of bubble condenser system to maximum air loading \\
Test 9 & MSLB & Response of bubble condenser system to maximum steam loading \\
Test 12 & SB LOCA & Observation of condensation oscillations \\
\hline
\end{tabular}

and to $\sim 300 \mathrm{~kg} / \mathrm{s}$ at $55 \mathrm{~s}$. The subcooled water is discharged through the break during the whole transient.

An instantaneous double-ended guillotine break of the MCL DN500 is considered as a limiting design basis LOCA, that is, the design basis LOCA defining the necessary capacity of the accident localization system (hermetic compartments, $\mathrm{BC}$, and spray system).

For design basis accidents, the following design criteria are considered (specific for the Kola NPP, unit 3, i.e., different from other units with BCC):

(i) maximum absolute pressure and temperature in hermetic compartments shall not exceed 0.20 MPa and $128^{\circ} \mathrm{C}$, respectively;

(ii) an under pressure not exceeding 0.0196 MPa shall be created in hermetic compartments within 30 minutes (minimum absolute pressure shall not be below $0.078 \mathrm{MPa})$.

The test scenarios for LB LOCA are developed for different stages of the accident. The reason for that is as follows. We try to obtain coincidence with scaled $1: 100$ NPP leak functions (mass flow rate and enthalpy) by varying of the nozzle diameter. Satisfied coincidence during a relatively long time $(\sim 20-30 s)$ is not reached for any values of nozzle diameter due to some limitations inherent to the test facility. So two criteria for selection of necessary nozzle diameter are used. First criterion is connected with coincidence of maximum flow rates to reproduce maximal loads on $\mathrm{BC}$ system and second one is coincidence of total discharged mass and energy for first $10 \mathrm{~s}$ to reproduce integral loads. So, it is decided to model different stages of LB LOCA (initial stage and middle-term stage) during different tests with corresponded nozzle diameter.

Tests 4 and 5 in Table 3 are aimed to model only the initial stage of LB LOCA, which is characterized by large pressure differences $(\sim 15-20 \mathrm{kPa})$ across the gap/cap system and $\mathrm{BC}$ walls and the nonuniformities of the flow distribution inside the BC. For example, Figure 5 shows scaled Kola-3 NPP MER and test facility MER for Test 4 calculated with the ATHLET code. The test facility MER provides adequate reproduction of the NPP MER during the very initial stage ( $\sim 5 s)$ and after that the test facility MER is more conservative than the NPP one.

The difference between Test 4 and Test 5 is related to the position of the discharge nozzle in SG box V1 (Test 4: near $\mathrm{BC}$ for providing large steam concentration in the air-steam flow directed to the $\mathrm{BC}$ (lower floors in $\mathrm{BC}$ tower), Test 5: far $\mathrm{BC}$ for providing large air concentration in the air-steam flow directed to the BC (upper floors in BC tower)). 


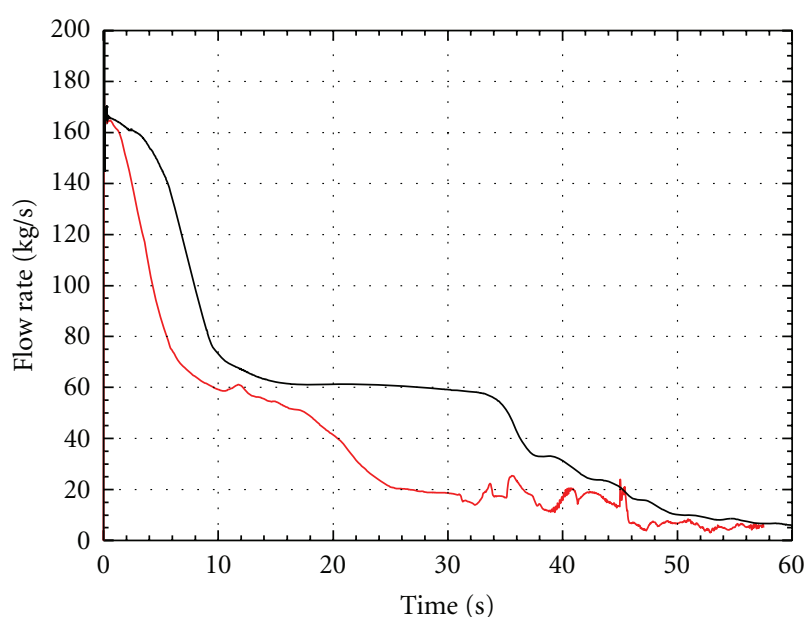

- NPP/100

- BC V-213

(a)

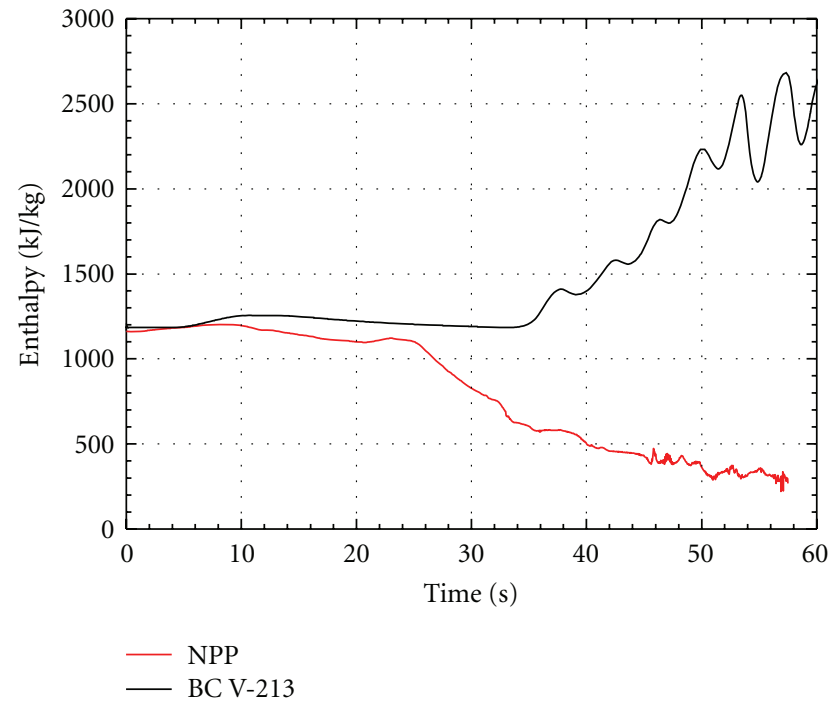

(b)

FIGURE 5: Calculated test facility and NPP MERs for Test 4. (a) Break flow rate, (b) break enthalpy.

TABLE 4: Initial conditions of LB LOCA.

\begin{tabular}{lc}
\hline Parameter & Value \\
\hline Upper plenum pressure, $(\mathrm{MPa})$ & 12.24 \\
Core outlet temperature of coolant, $\left({ }^{\circ} \mathrm{C}\right)$ & 297.2 \\
Core inlet temperature of coolant, $\left({ }^{\circ} \mathrm{C}\right)$ & 267.1 \\
Loop flow rate, $(\mathrm{kg} / \mathrm{s})$ & 1463 \\
Main coolant pump pressure difference, $(\mathrm{MPa})$ & 0.47 \\
Pressurizer temperature, $\left({ }^{\circ} \mathrm{C}\right)$ & 325.7 \\
Pressurizer level, $(\mathrm{m})$ & 5.97 \\
Core power, $(\mathrm{MW})$ & 1375 \\
Steam generator pressure, $(\mathrm{MPa})$ & 4.66 \\
Live steam temperature, $\left({ }^{\circ} \mathrm{C}\right)$ & 259.5 \\
Feed water temperature, $\left({ }^{\circ} \mathrm{C}\right)$ & 222.8 \\
Live steam and feed water flow rate, $(\mathrm{kg} / \mathrm{s})$ & 128 \\
Water level in steam generator, $(\mathrm{m})$ & 1.831 \\
Power of steam generators, $(\mathrm{MW})$ & 1375 \\
Initial pressure in hydroaccumulators, $(\mathrm{MPa})$ & 5.9 \\
Initial water level in hydroaccumulators, $(\mathrm{m})$ & 5.6 \\
Water temperature in hydroaccumulators, $\left({ }^{\circ} \mathrm{C}\right)$ & 55 \\
Pressure in low pressure system, $(\mathrm{MPa})$ & 0.695 \\
\hline
\end{tabular}

Test 1 is aimed to model (in average) thermohydraulic processes under LB LOCA conditions for the time period $\sim 100$ s, when the bubble condenser and hermetic boxes are mostly impacted by the break. Special pretest calculation procedure, based on the methodology developed in the frame of the German-Russian Project INT 9142 [8], was performed to determine the scenario of Test 1 . Main stages of this procedure are the following:

(i) defining with the COCOSYS code main parameters ranges, specifying thermohydraulic conditions for bubble-condenser inlet for the Kola NPP, based on the Kola NPP data base prepared in frame of the Tacis Project RF/TS [9];
TABLE 5: Chronology of events during LB LOCA.

\begin{tabular}{lc}
\hline Time, sec & Event \\
\hline 0.0 & Double-ended guillotine break \\
0.0 & Total loss of electricity \\
0.0 & Turbine isolation begins \\
0.03 & Scram signal \\
0.1 & More then three main coolant pumps dropped out \\
4.76 & Pressurizer pressure $<10,8 \mathrm{MPa}$ \\
5.41 & Start of hydroaccumulator injection to downcomer \\
5.46 & Start of hydroaccumulator injection to upper plenum \\
6.99 & Pressurizer level $<2.76 \mathrm{~m}$ \\
8.22 & Pressurizer level $<2.26 \mathrm{~m}$ \\
16.00 & Start of high-pressure injection system \\
32.90 & Start of low-pressure injection system \\
\hline
\end{tabular}

(ii) these parameters (criteria) are criterion C1: mass flow density entering the $\mathrm{BC}$ gap/caps $\left[\mathrm{kg} /\left(\mathrm{s}^{*} \mathrm{~m}^{2}\right)\right]$

$$
C_{1}=\frac{G}{A \cdot n}
$$

with $G$ : total mass flow entering all gap/caps, $[\mathrm{kg} / \mathrm{s}]$, $A$ : cross section area of one gap/caps system, $\left[\mathrm{m}^{2}\right], n$ : number of gap/caps systems, [-].

criterion $\mathrm{C2}$ : specific steam mass flow entering the $\mathrm{BC}$ water layer $\left[\mathrm{kg} /\left(\mathrm{s}^{*} \mathrm{t}\right)\right]$

$$
C_{2}=\frac{n \cdot G_{\text {steam }}^{\text {gap }} / \text { cap }}{m_{\text {water }}}
$$

with $n$ : number of gap/caps systems, [-], $m_{\text {water }}$ : water mass, $[\mathrm{t}], G_{\text {steam }}^{\text {gap }}$ : steam mass flow entering a gap/cap system, $[\mathrm{kg} / \mathrm{s}]$. 


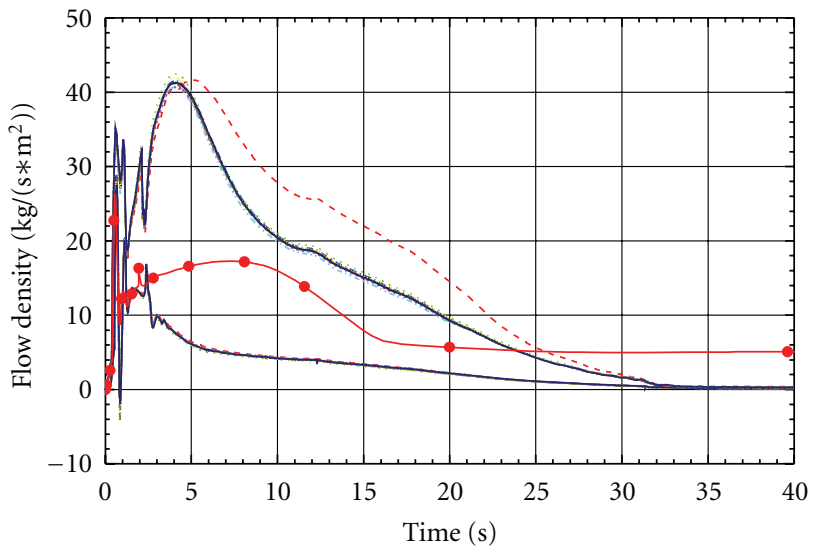

(a)

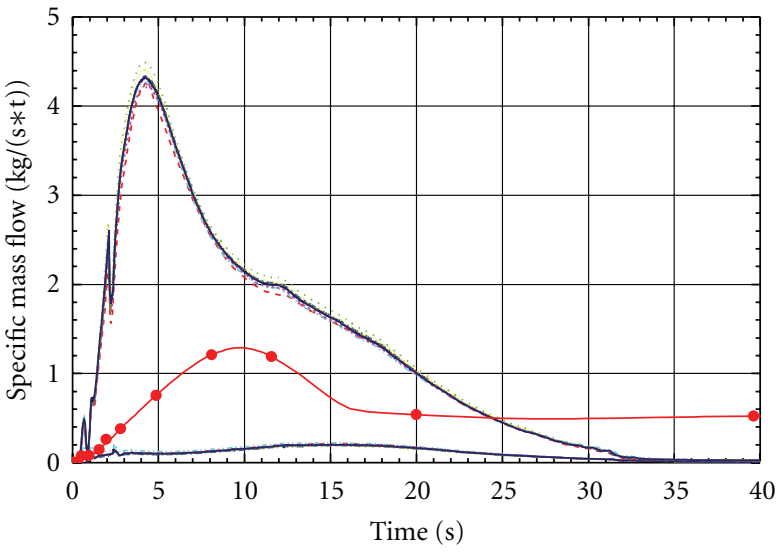

(b)

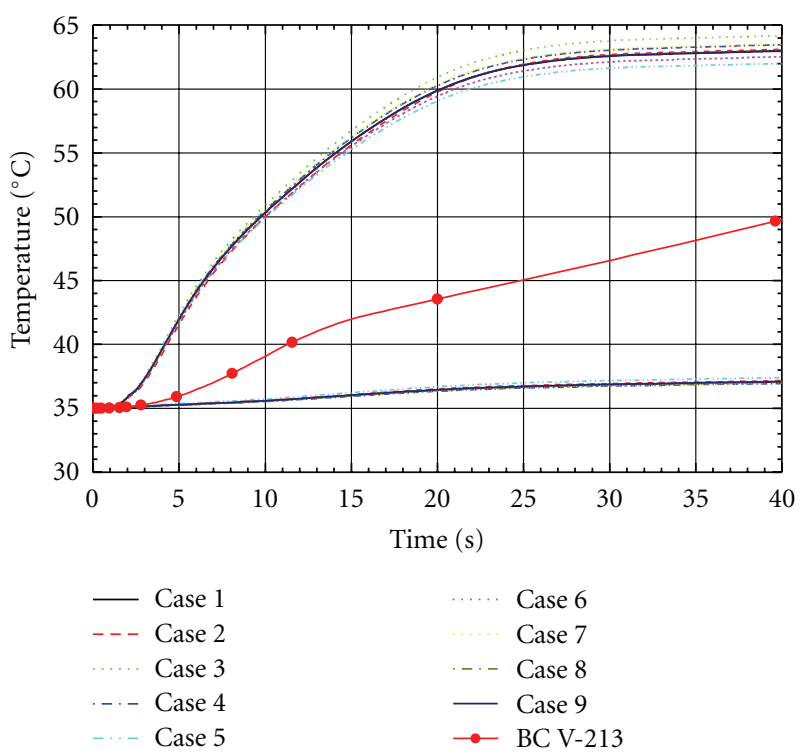

(c)

Figure 6: Criteria C1-C3. (a) C1: mass flow density entering BC gap/caps (and NPP bandwidth), (b) C2: specific steam mass flow entering BC water layer (and NPP bandwidth), (c) C3: BC water temperature (and NPP bandwidth).

criterion $\mathrm{C} 3$ : $\mathrm{BC}$ water temperature $\left[{ }^{\circ} \mathrm{C}\right]$. These criteria will be calculated for the NPP (beside the main parameters pressure, temperature and pressure differences) for the lowest and the uppermost condensing trays for different initial and boundary conditions of the defined LB LOCA scenario, which results in bandwidths;

(iii) performing iterative calculations of coolant blowdown from the high-pressure vessel system by means of ATHLET code and processes in the bubble-condenser system and BC V-213 compartments by means of the COCOSYS code in order to define the test scenario, allowing to reach $\mathrm{BC}$ loading conditions representative for the reference NPP, Figure 6.

Test scenarios for MSLB and SB LOCA tests are specified without any difficulties.

As a result of pretest calculations [10], initial and boundary conditions of the tests (Table 6) have been specified.
Initial water level in the $\mathrm{BC}$ tray is $500 \mathrm{~mm}$, and initial temperature of the tray water is about $35^{\circ} \mathrm{C}$ for all tests.

\section{Main Test Results}

In accordance with specified test scenarios six tests were performed for qualification of BC system under accident conditions at Kola-3 NPP [11-16]. Main experimental results are summarized in Table 7.

Analysis of the test results has shown that calculated initial conditions and test scenarios were properly adjusted in the tests.

\section{Posttest Analysis of the Tests Performed at BC V-213 Test Facility}

5.1. Modeling of High-Pressure System of BC V-213 Test Facility with the ATHLET Code. The ATHLET 1.2 Cycle D 
TABLE 6: Initial and boundary conditions of the tests.

\begin{tabular}{|c|c|c|c|c|c|c|}
\hline $\begin{array}{l}\text { Test facility } \\
\text { parameter }\end{array}$ & Test 1 & Test 4 & Test 5 & Test 7 & Test 9 & Test 12 \\
\hline$V_{v 1}$ & $\begin{array}{c}\text { Fully filled with } \\
\text { water } \\
T=271.5^{\circ} \mathrm{C}\end{array}$ & $\begin{array}{c}\text { Fully filled with } \\
\text { water } \\
T=271.5^{\circ} \mathrm{C}\end{array}$ & $\begin{array}{l}\text { Fully filled with } \\
\text { water } \\
T=271.5^{\circ} \mathrm{C}\end{array}$ & $\begin{array}{c}\text { Water level } \\
2.325 \mathrm{~m} \\
T=259^{\circ} \mathrm{C}\end{array}$ & $\begin{array}{c}\text { Water level } \\
2.325 \mathrm{~m} \\
T=259^{\circ} \mathrm{C}\end{array}$ & $\begin{array}{c}\text { Fully filled with } \\
\text { water } \\
T=271.5^{\circ} \mathrm{C}\end{array}$ \\
\hline$V_{v 2}$ & $\begin{array}{c}\text { Fully filled with } \\
\text { water } \\
T=298.5^{\circ} \mathrm{C}\end{array}$ & $\begin{array}{l}\text { Fully filled with } \\
\text { water } \\
T=298.5^{\circ} \mathrm{C}\end{array}$ & $\begin{array}{l}\text { Fully filled with } \\
\text { water } \\
T=298.5^{\circ} \mathrm{C}\end{array}$ & $\begin{array}{c}\text { Water level } \\
1.370 \mathrm{~m} \\
T=259^{\circ} \mathrm{C}\end{array}$ & $\begin{array}{c}\text { Water level } \\
1.370 \mathrm{~m} \\
T=259^{\circ} \mathrm{C}\end{array}$ & It is not used \\
\hline$V_{v 3}$ & It is not used & It is not used & It is not used & Steam $T=259^{\circ} \mathrm{C}$ & Steam $T=259^{\circ} \mathrm{C}$ & It is not used \\
\hline$V_{v 4}$ & It is not used & It is not used & It is not used & It is not used & It is not used & It is not used \\
\hline$V_{v 5}$ & $\begin{array}{c}\text { Water level } \\
1.270 \mathrm{~m} \\
T=327^{\circ} \mathrm{C}\end{array}$ & $\begin{array}{c}\text { Water level } \\
1.270 \mathrm{~m} \\
T=327^{\circ} \mathrm{C}\end{array}$ & $\begin{array}{c}\text { Water level } \\
1.270 \mathrm{~m} \\
T=327^{\circ} \mathrm{C}\end{array}$ & Steam $T=259^{\circ} \mathrm{C}$ & Steam $T=259^{\circ} \mathrm{C}$ & $\begin{array}{c}\text { Water level } \\
3.000 \mathrm{~m} \\
T=327^{\circ} \mathrm{C}\end{array}$ \\
\hline System pressure & $12.5 \mathrm{MPa}$ & $12.5 \mathrm{MPa}$ & $12.5 \mathrm{MPa}$ & $4.7 \mathrm{MPa}$ & 4.7 MPa & $12.5 \mathrm{MPa}$ \\
\hline $\begin{array}{l}\text { Additional supply } \\
\text { of steam } \\
(P=8 \mathrm{MPa} \text {, } \\
\left.T=300^{\circ} \mathrm{C}\right) \text { into } \\
V_{v 1}\end{array}$ & It is not used & It is not used & It is not used & $\begin{array}{c}0.4 \mathrm{~kg} / \mathrm{s} \\
(100-500 \mathrm{~s}) \\
0.2 \mathrm{~kg} / \mathrm{s} \text { (after) }\end{array}$ & $\begin{array}{c}0.4 \mathrm{~kg} / \mathrm{s} \\
(100-500 \mathrm{~s}) \\
0.2 \mathrm{~kg} / \mathrm{s} \text { (after) }\end{array}$ & It is not used \\
\hline $\begin{array}{l}\text { Position of } \\
\text { discharge nozzle }\end{array}$ & Middle & Near & Far & Far & Fear & Middle \\
\hline Nozzle diameter & $45 \mathrm{~mm}$ & $56 \mathrm{~mm}$ & $56 \mathrm{~mm}$ & $56 \mathrm{~mm}$ & $56 \mathrm{~mm}$ & $4 \mathrm{~mm}$ \\
\hline
\end{tabular}

TABLE 7: Summary of main experimental results.

\begin{tabular}{|c|c|c|c|c|c|c|c|}
\hline \multirow{2}{*}{ No. } & \multirow{2}{*}{ Parameter } & \multicolumn{6}{|c|}{ Tests } \\
\hline & & $\begin{array}{c}\text { Test } 4 \\
\text { LB LOCA }\end{array}$ & $\begin{array}{c}\text { Test } 5 \\
\text { LB LOCA }\end{array}$ & $\begin{array}{c}\text { Test } 1 \\
\text { LB LOCA }\end{array}$ & $\begin{array}{c}\text { Test } 7 \\
\text { MSLB }\end{array}$ & $\begin{array}{l}\text { Test } 9 \\
\text { MSLB }\end{array}$ & $\begin{array}{c}\text { Test } 12 \\
\text { SB LOCA }\end{array}$ \\
\hline (1) & $\begin{array}{l}\text { Maximum absolute pressure in box } V_{1} \text {, } \\
(\mathrm{MPa})\end{array}$ & 0,202 & 0,214 & 0,197 & 0,1835 & 0,175 & 0,111 \\
\hline (2) & $\begin{array}{l}\text { Time of achievement of maximum } \\
\text { pressure in box } V_{1},(\mathrm{~s})\end{array}$ & $8,07-9,77$ & 8,89 & $70-90$ & $90-100$ & $90.5-96$ & $353-388$ \\
\hline (3) & $\begin{array}{l}\text { Maximum pressure difference across } \mathrm{BC} \text {, } \\
(\mathrm{kPa})\end{array}$ & 14,55 & 15,73 & 11,62 & 7,8 & 7,7 & 4,9 \\
\hline (4) & $\begin{array}{l}\text { Maximum absolute pressure in air trap } \\
V_{5},(\mathrm{MPa})\end{array}$ & 0,193 & 0,200 & 0,191 & 0,177 & 0,169 & 0,106 \\
\hline (5) & Maximum temperature in box $V_{1},\left({ }^{\circ} \mathrm{C}\right)$ & 120 & 122 & 120 & 118 & 118 & 86 \\
\hline (6) & Maximum temperature of $\mathrm{BC}$ water, $\left({ }^{\circ} \mathrm{C}\right)$ & 78 & 78 & 60 & 56 & 63 & 38,5 \\
\hline (7) & Time of check valve closure, (s) & 90 & 87 & 114 & 212 & 185 & 2240 \\
\hline (8) & $\begin{array}{l}\text { Absolute pressure in box } V_{3} \text { when relief } \\
\text { valve opened, }(\mathrm{MPa})\end{array}$ & 0,19 & 0,17 & 0,191 & 0,174 & 0,167 & 0,106 \\
\hline (9) & Time of relief valve opening, (s) & 88,6 & 90,3 & 115 & 207,6 & 180 & 2300 \\
\hline$(10)$ & Occurrence of reverse flow from $\mathrm{BC}$ & no & yes & no & no & no & no \\
\hline$(11)$ & Break location & near & far & middle & far & near & middle \\
\hline
\end{tabular}

version [6] was used for performing posttest analysis of coolant discharging.

The corresponding ATHLET nodalization scheme is presented in Figure 7. It consists of 41 thermofluid objects with 331 control volumes and 337 junctions. Also 46 heat structures with 326 heat conduction volumes (1326 layers) are used for description of tubes' and vessels' walls and thermoinsulation. The object AMBIENT (time-dependent volume) with constant pressure $0.1 \mathrm{MPa}$ and temperature $25^{\circ} \mathrm{C}$ is used to model heat exchange with the environment.
Heat transfer coefficient from the surface of thermoinsulation to the environment equals to $10 \mathrm{~W} /\left(\mathrm{m}^{2} \mathrm{~K}\right)$.

Since the discharge mass flow rate is one of the most important thermal-hydraulic boundaries dominating the course of a LOCA or a blowdown experiment, an accurate simulation of the critical flow is required. The one-dimensional thermodynamic nonequilibrium model CDR1D of ATHLET is used with consideration of geometric details of the discharge flow path for calculation of the critical discharge. 


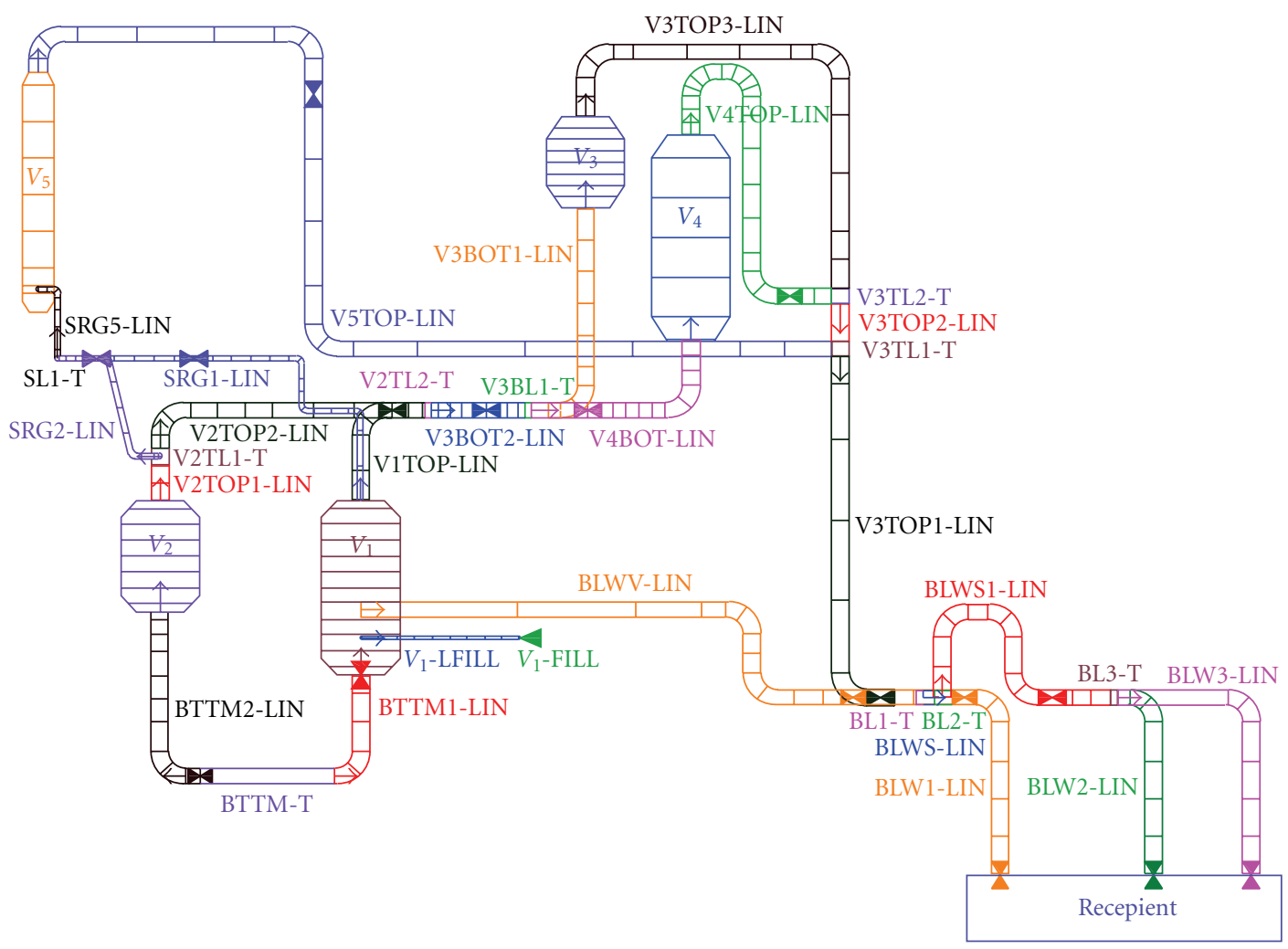

FIgURE 7: Nodalization scheme of the high-pressure system.

Form loss coefficients essentially influence the blowdown dynamics. Their values were based on [17].

The ATHLET input deck, prepared by EREC, for modeling of high-pressure system of BC V-213 test facility was carefully reviewed by GRS experts in the frame of the GermanRussian Project INT 9142 [8]. Their comments permitted to improve the ATHLET input deck and the quality of modeling of thermohydraulic processes in the high-pressure system of the BC V-213 test facility.

5.2. Modeling of BC and Compartments of BC V-213 Test Facility with the COCOSYS Code. One of the main purposes of the posttest analysis was the development of the COCOSYS basic input deck, which allows to adequately simulate all tests performed in the frame of the Tacis Project R2.01/99. Only the final version of the input deck is described here.

The nodalization of the BC V-213 test facility consists of 24 zones, 34 atmospheric and 21 drain junctions, 4 pump systems, and 109 heat conducting structures. The input deck is based on a deck developed by GRS in frame of the GermanRussian Project INT 9142 for analysis of the SLB experiments. This input deck was modified in accordance with modifications of the BC V-213 test facility [4].

The corresponding nodalization scheme is presented in Figure 8 .

The subdivision of the SG box $V_{1}$ into three zones reflects the three possible break locations. In the lower parts of the facility compartments water can accumulate. Thus, they are modelled as separate sumps. At initial time a small amount of water is assumed in the sumps. Water carryover between the nodes is considered by values reducing downstream from the break location.

Zones are connected by atmospheric junctions to simulate the transport of accident-generated 2-phase 2-component mixture.

The gasroom of the $\mathrm{BC}$ is connected with the air trap $\mathrm{V}_{5}$-AT via the dynamic flap F1 to model the two DN173 check valves including their inlet protection ducts. It should be noted that one DN173 check valve installed at BC V-213 test facility simulates twenty four DN500 check valves (2 in series) installed at Kola NPP in the scale 1: 100 with regards to cross-section area. Opening pressure difference both check valve DN173 and check valve DN500 is the same $(0.49 \mathrm{kPa})$, full opening of them is achieved under the pressure difference $9.8 \mathrm{kPa}$.

The full-scale DN250 relief valve connecting BC gasroom and BC shaft is simulated by the dynamic flap F2. Flap F2 will be locked in closed position, if the pressure in the $\mathrm{BC}$ shaft rises higher than locking pressure value. The value of unlocking pressure for F2 is changed from $163.7 \mathrm{kPa}$ in pretest calculations to corresponding values observed in the tests (Table 7), for example, $190.0 \mathrm{kPa}$ in Test 4.

The facility compartment system is assumed to be leak tight. The two special rupture disks and their structures in the SG compartment $V_{2}$, designed to protect the facility from overpressure failure, were considered as heat structures only.

Drain junctions in COCOSYS are foreseen to simulate flow processes of water, for instance the drainage of injected water or condensate (drain junctions D1...D15) or the flow 


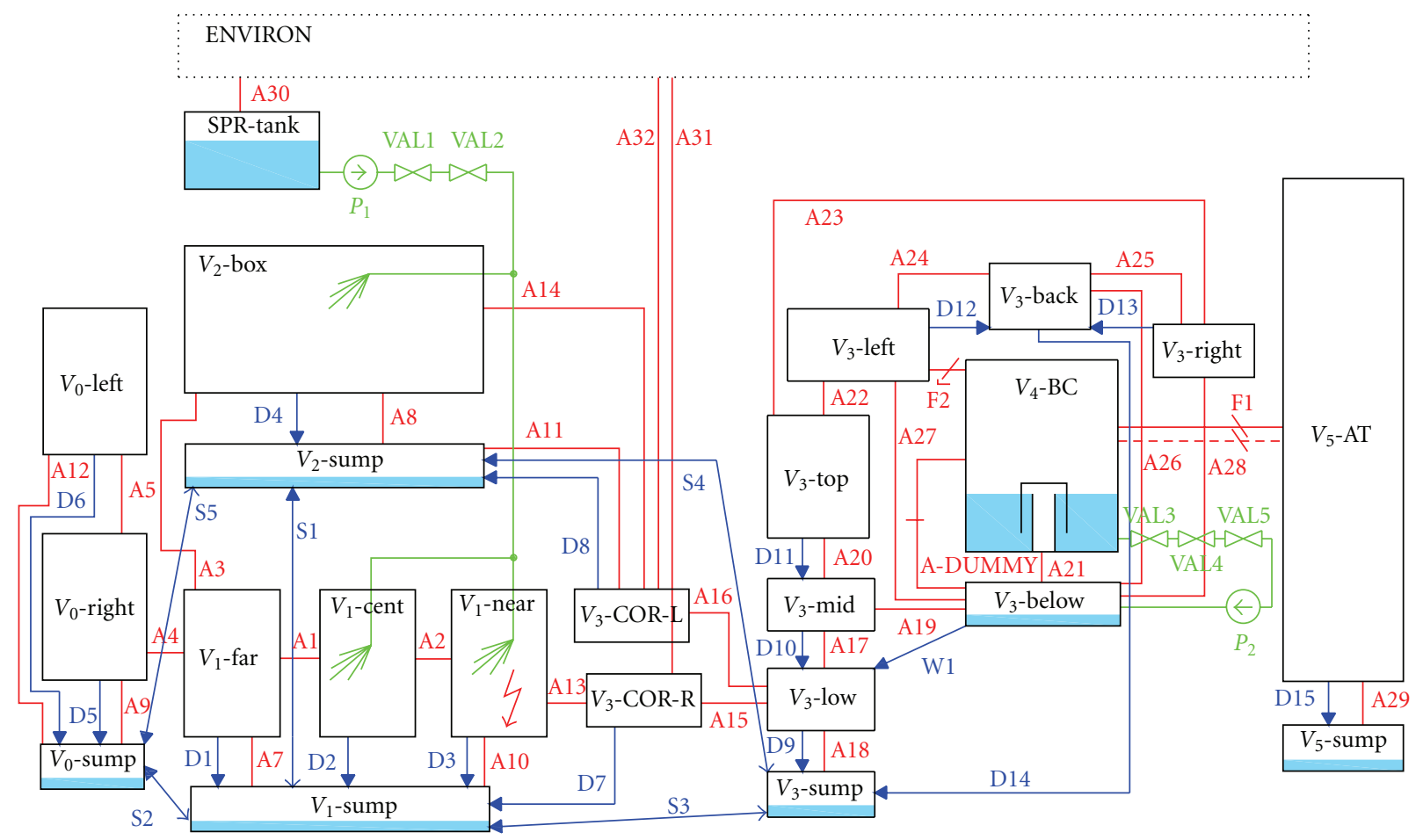

FIGURE 8: COCOSYS, 24 zone nodalization for the EREC BC V-213 test facility.

between different sumps to equalise the water surface levels (S1...S5). It is assumed that during any experiment all drain junctions to the facility outside are closed and, thus, not considered in the input deck.

The spray system, which injects water into both SG boxes $V_{1}$ and $V_{2}$, is simulated by a pump system. Activation of the spray system is to be set according the test performance.

Heat transfer and heat conduction processes are considered by so-called heat slabs. For each zone the relevant surfaces were defined as floor, side walls, and ceiling. The BC walls are subdivided into different heat slabs to consider that wall sides are linked with the pool (water), the gasroom, or the gap/cap system.

Some parts of the wall surfaces in the SG boxes $V_{1}$ and $V_{2}$ in the BC shaft volume $V_{3}$ and in the air trap $V_{5}$ are insulated with wooden plates. This is a known important uncertain boundary condition. This insulation is considered in the input deck with reasonable geometry and physical material properties. All surfaces except the stainless steel walls of the bubble condenser are treated to be coated with paint (epoxide layer). According to [8] modified material properties of reinforced concrete and wood are used.

In the 24 zone data set, all 18 gap/cap systems of the BC V-213 facility are modelled by one zone of the DRASYS type. Consequently, only an average BC behaviour is simulated (average pool temperature heat up).

To model the water carryover into the gasroom and the air trap special pumps are defined. The corresponding timedependent water mass flow rates were defined as about $50 \%$ of the gas mass entering the gasroom and the air trap (via junction F1).
In the applied developer version COCOSYS 2.0AA (status 2005) the DRASYS zone model was improved on the basis of EREC BC V-213 experiments to permit the simulation of humid air flowing through the BC water pool to the gasroom. Up to the earlier code version V2.0v2 only dry air option is available. Corresponding additional parameter AWET = 1.0 in the input decks was incorporated to provide $100 \%$ humidity of the mentioned air flow. The COCOSYS model parameter AFAL (factor of gas cooling during carryover) was set to 0.75 . Thus, a better coincidence of the calculated and measured atmospheric temperature in the $\mathrm{BC}$ gasroom was achieved.

The results of the ATHLET posttest calculations as mass and energy release rate were used as main boundary of the COCOSYS calculations.

Initial and boundary conditions for the particular tests were set in accordance with experimental data [11-16].

5.3. Tests 1, 4, and 5 (LB LOCA). Tests 4 and 5 are aimed to model thermohydraulic processes under LB LOCA conditions taking into account large steam (Test 4) or air (Test 5) concentration in the air-steam flow before BC tray in order to investigate mainly the maximum pressure difference across the gap/cap system and $\mathrm{BC}$ walls and the nonuniformities of the flow distribution inside the $\mathrm{BC}$. The scenarios of these tests were determined by means of ATHLET calculations. The intention of these calculations was to adjust the coolant blowdown from the BC V-213 high-pressure vessel system in order to meet coolant blowdown parameters at the NPP reduced by 100 times. 

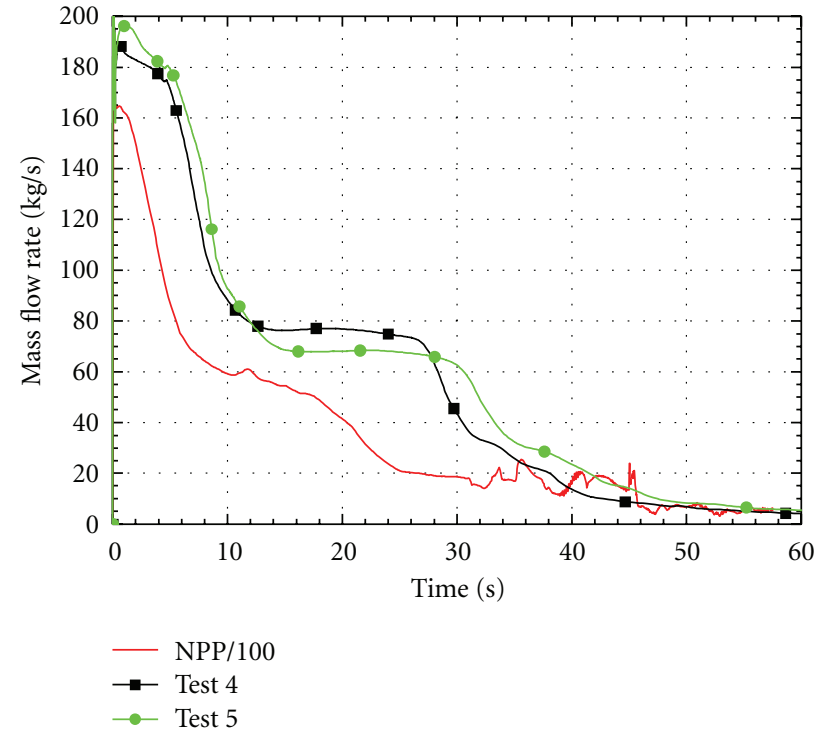

(a)

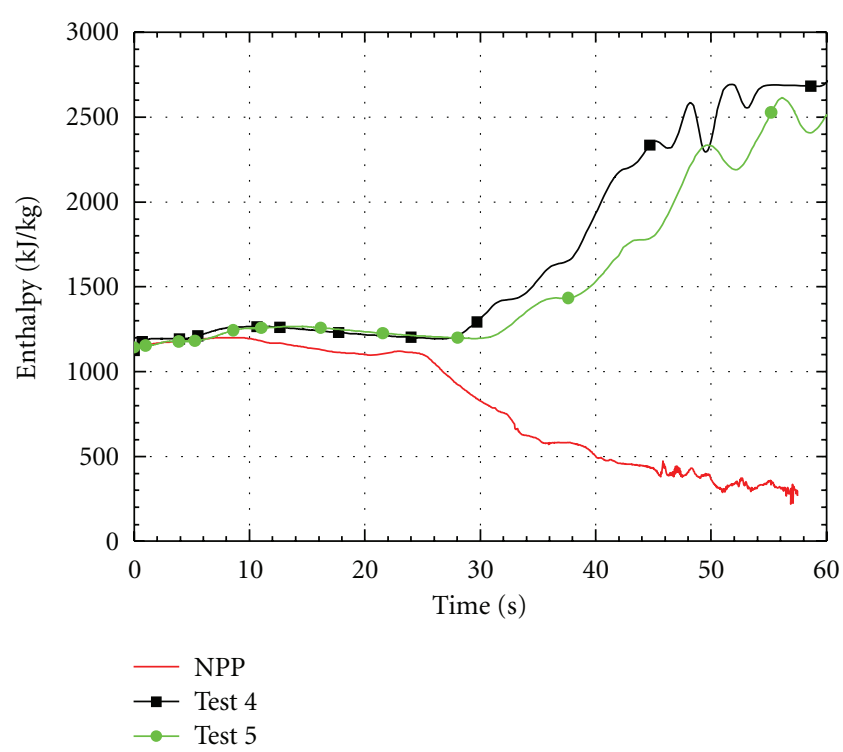

(b)

FIGURE 9: Comparison of experimental MERs with NPP scaled MER. Tests 4 and 5. (a) Break mass flow rate, (b) break enthalpy.

The comparison of the test results with pretest calculations has shown that initial conditions and test scenarios obtained in the pretest analysis were adjusted adequately at the BC V-213 test facility. However, some deviations between initial and boundary conditions assumed in the ATHLET pretest calculations and those realised in the test took place, for example, the initial water level in $V_{v 5}$. So, the initial and boundary conditions realized in the test were finally used in the ATHLET posttest calculations.

The aim of the posttest analysis of thermo-hydraulic processes in the high-pressure system is to determine MER (coolant mass flow rate and specific enthalpy). The measurement of the mass flow rate of discharged coolant with VTI tube is valid only during first seconds, when discharge of subcooled water takes place. Mass flow rate of the twophase mixture is not measured correctly by this kind of gauge. So, the MER should be determined by posttest analysis with the ATHLET code; if ATHLET results agree well with other significant experimental data (pressure, temperature, collapsed level, and mass flow rate of single-phase coolant), so it is possible to conclude that ATHLET provides reliable MER as for single-phase and two-phase regions.

Comparison of experimental MERs determined by posttest analysis with NPP scaled MER is shown in Figure 9. Experimental mass flow rates are greater than NPP ones; break enthalpies are essentially differed after $25 \mathrm{~s}$, when steam discharge starts at the test facility. However, the main aim of Tests 4 and 5 is to model only the initial stage of LB LOCA $(\sim 2 \mathrm{~s})$, which is adequately adjusted at the test facility.

Test 4 (LB LOCA) was analyzed with COCOSYS code in detail. Many variant calculations were performed to adequately reproduce behaviors of experimental parameters. Other tests were analyzed with model parameters adjusted for Test 4 .
Posttest analysis of thermal-hydraulic processes in hermetic compartments and BC with the COCOSYS code has shown reasonable agreement between calculated and experimental data. Comparison of $\mathrm{BC}$ pressure differences is presented in Figure 10. Predicted maximum values of the pressure difference are higher and occur earlier than experimental values. Reasonable explanation of it is elastic deformation of the BC steel walls during the very initial phase, not considered in the code. A second reason might be the blocking of the left channel by the counter-current flow revealed in the test and not simulated in the calculation [18].

Test 1 was aimed to be the representative LB LOCA with regard to the maximum absolute pressure and temperature in the compartment system of the reference NPP Kola-3. The test scenario was determined with iterative ATHLET and COCOSYS pretest calculations based on the above-described methodology to realize adequate $\mathrm{BC}$ loading conditions at the test facility as in the Kola-3 NPP [8]. Figure 11 illustrates comparison of criteria $\mathrm{C} 1-\mathrm{C} 3$ obtained in the posttest analysis of Test 1 with the COCOSYS code and corresponding criteria for NPP case. A similar picture as for pretest calculations is obtained: during $\sim 22 \mathrm{~s}$ criteria $\mathrm{C} 1$ (mass flow density entering the $\mathrm{BC}$ gap/caps) and $\mathrm{C} 2$ (specific steam mass flow entering the BC water layer) lie inside NPP bandwidth, after that the test is conservative in comparison with NPP case. These peculiarities are explained by exceeding of experimental MER, especially after $20 \mathrm{~s}$. It is difficult to reproduce the complex behaviour of the NPP primary system at the late stage of LB LOCA (after 20 s) using simple three vessels configuration of the BC V-213 test facility highpressure system. As to the third criterion $\mathrm{C} 3$ (temperature of BC water), both experimental and post calculated curves lie inside the NPP bandwidth. The curves Cases 1 to 9 are result 


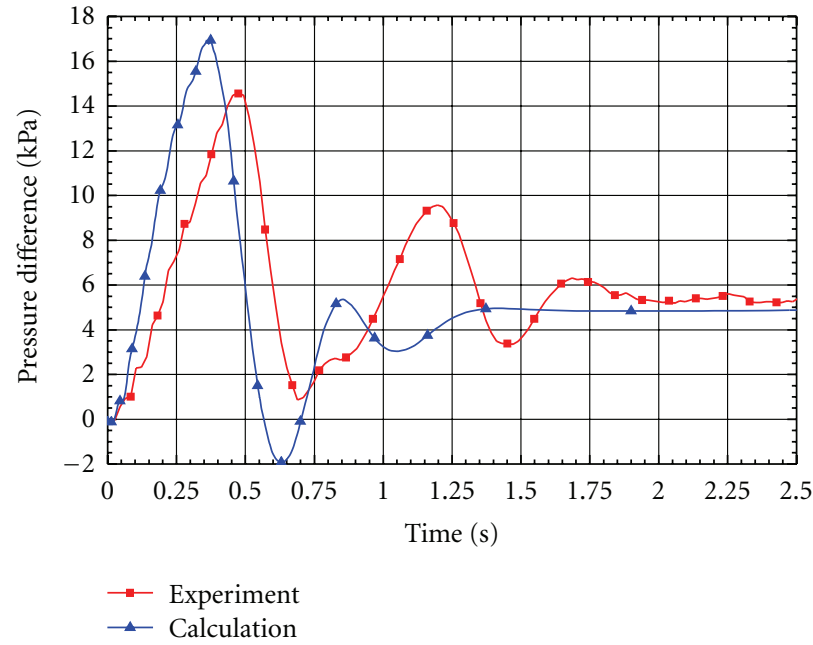

(a)

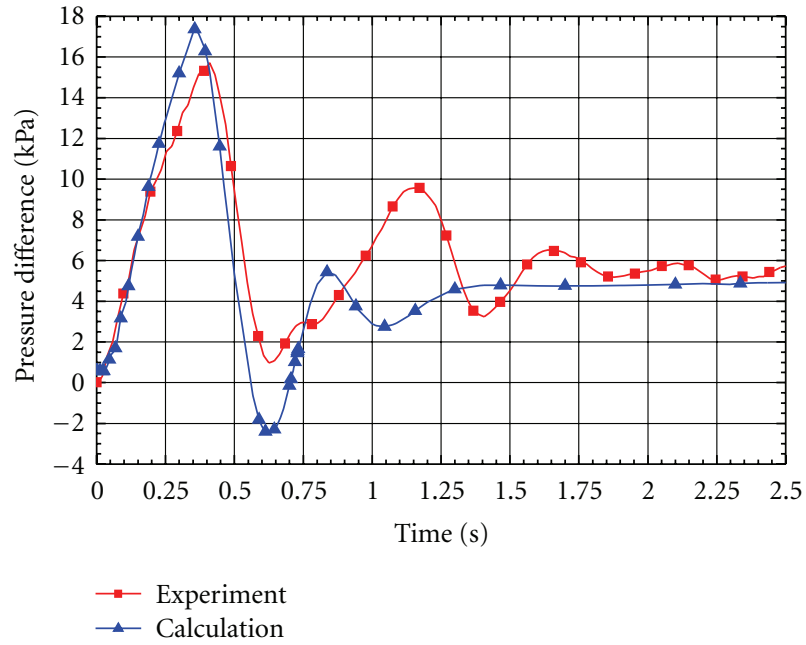

(b)

Figure 10: Experimental and calculated pressure difference across BC walls. (a) Test 4; (b) Test 5.

of the sensitivity study for bandwidth determination. They are described in [10].

So, adequate BC loads were obtained in the BC V-213 test facility in comparison with NPP in accordance with applied methodology.

In Figure 11(d) the calculated and measured pressures in the box $V_{1}$ and in the air trap $V_{5}$ are compared. Measurement uncertainties due to limited accuracy of gauges are illustrated with error bars on experimental curves. In the first phase the pressurisation is overestimated, whereas later on the calculation lays inside the measurement uncertainty range.

5.4. Tests 7 and 9 (MSLB). Tests 7 and 9 are aimed to model thermo-hydraulic processes under MSLB conditions taking into account large air (7) or steam (9) concentration in the air-steam flow before $\mathrm{BC}$ tray. The scenarios of these tests were determined by means of ATHLET calculations as explained above for Tests 1, 4, and 5. Finally, the NPP scaled MER is adequately reproduced in the tests, Figure 12.

Posttest analysis of thermal-hydraulic processes in the hermetic compartments and BC with the COCOSYS code has shown a good agreement between calculated and experimental data. A comparison of experimental and calculated absolute pressures in boxes $V_{1}$ and $V_{5}$ for Test 7 is shown on Figure 13. Measurement uncertainties due to limited accuracy of gauges are illustrated with error bars on experimental curves. For the box $V_{1}$ a rather good agreement is obtained on the whole time range except the period from 200 to $400 \mathrm{~s}$. The calculated maximum value of the absolute pressure in the box $V_{1}$ is in good coincidence with experimental one $(0.185 \mathrm{MPa}$ and $0.184 \mathrm{MPa}$, correspondingly, but the difference is within uncertainty range of the gauge). In the box $V_{5}$ calculated absolute pressure is slightly higher than experimental one all the time. The maximum difference amounts to about $7 \mathrm{kPa}$ at $1800 \mathrm{~s}$; it is slightly larger than uncertainty range. Similar results were obtained in posttest analysis of Test 9 .
5.5. Test 12 (SB LOCA). Test 12 was aimed to model thermohydraulic processes under SB LOCA conditions. The scenario of this test was determined by means of ATHLET calculations as explained above.

Posttest analysis of the thermal-hydraulic processes in the boxes and $\mathrm{BC}$ has shown that loads on $\mathrm{BC}$ and hermetic compartments are practically negligible under SB LOCA conditions. The deviations of calculated and measured parameters are in the order of the gauge uncertainty (pressure) or less (temperature). The main idea of the SB LOCA test performance was to investigate experimentally whether the gap/cap systems tend to condensation oscillations under SB LOCA conditions. Main outcome of this test is that no condensation oscillations of the $\mathrm{BC}$ pool water were observed.

5.6. Main Calculated Results. Evaluating the results of posttest analysis with regard to the safety relevance, it can be concluded that LB LOCA conditions have higher degree of the safety relevance compared with MSLB and especially SB LOCA. Main thermal-hydraulic parameters characterizing loads on BC and hermetic compartments are presented in Table 8. It should be taken into account that Test 4 and Test 5 (both LB LOCA) were aimed to investigate only the initial stage of the accident and determine the maximum pressure difference across BC. These tests were not representative for maximum pressure and temperature in the hermetic compartments. Test 1 was aimed to be the representative LB LOCA with regard to the maximum pressure and temperature in the compartment system of the reference NPP Kola-3.

So, the COCOSYS code was successfully validated on experimental data concerning thermal-hydraulic processes in the $\mathrm{BC}$ and hermetic compartments at the $\mathrm{BC} \mathrm{V}-213$ test facility, which was a scaled model $(1: 100)$ of unit 3 of the Kola NPP. The next step is the application of the validated COCOSYS code for analyzing thermal-hydraulic processes in the hermetic compartments and $\mathrm{BC}$ loading during a corresponding accident at the Kola NPP. 


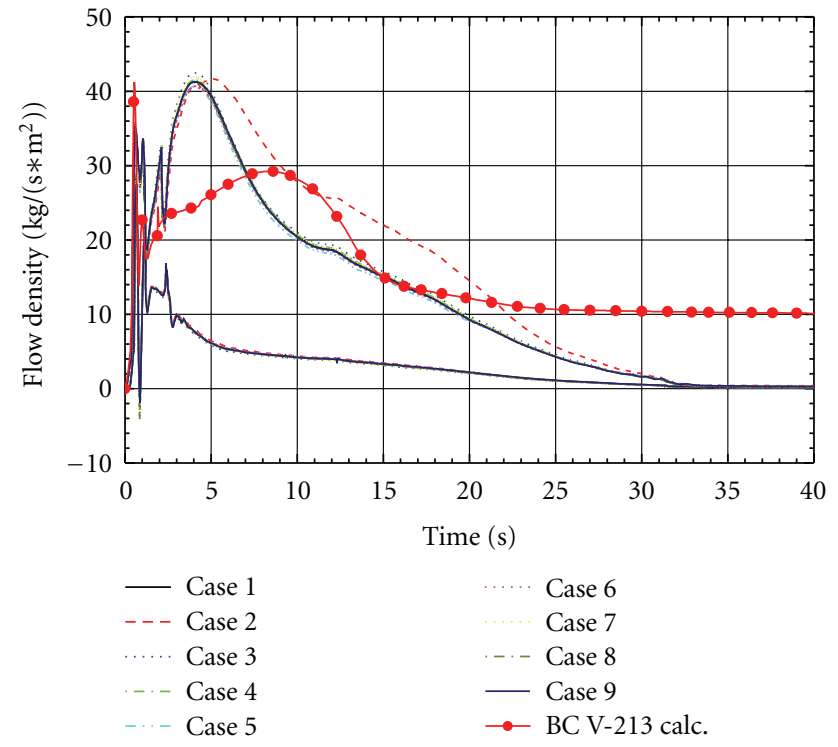

(a)

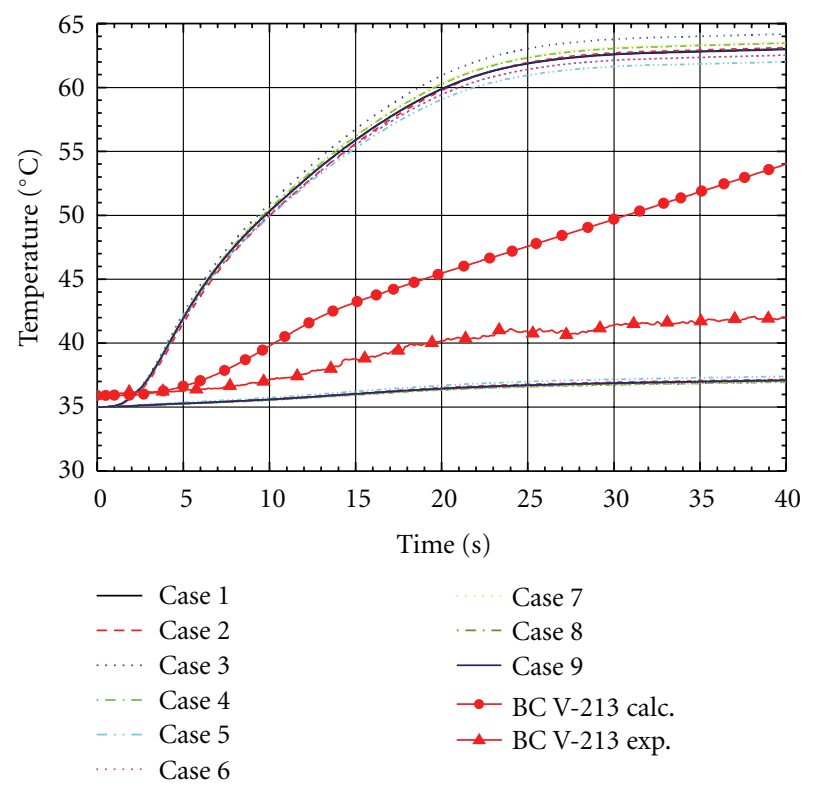

(c)

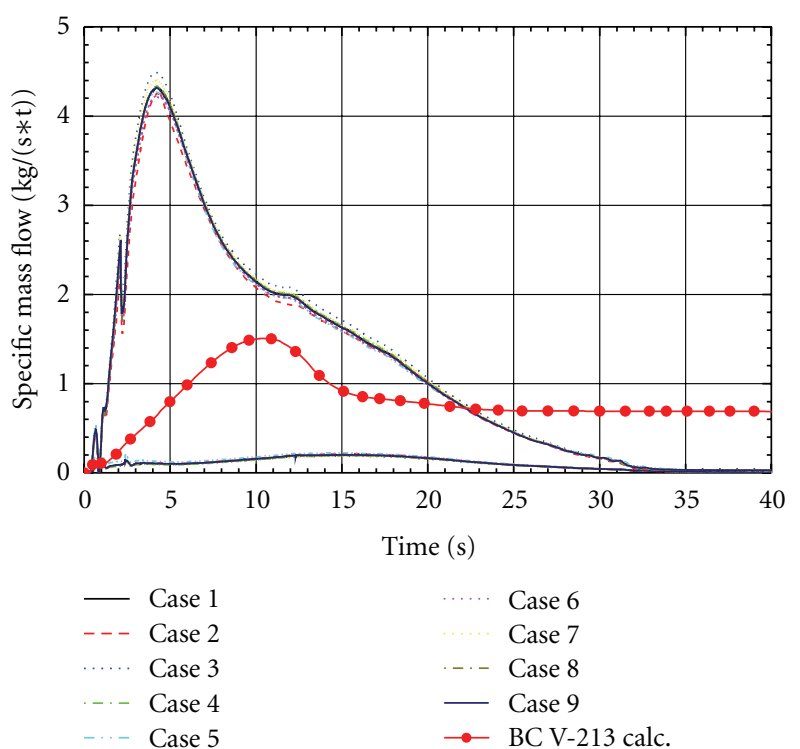

(b)

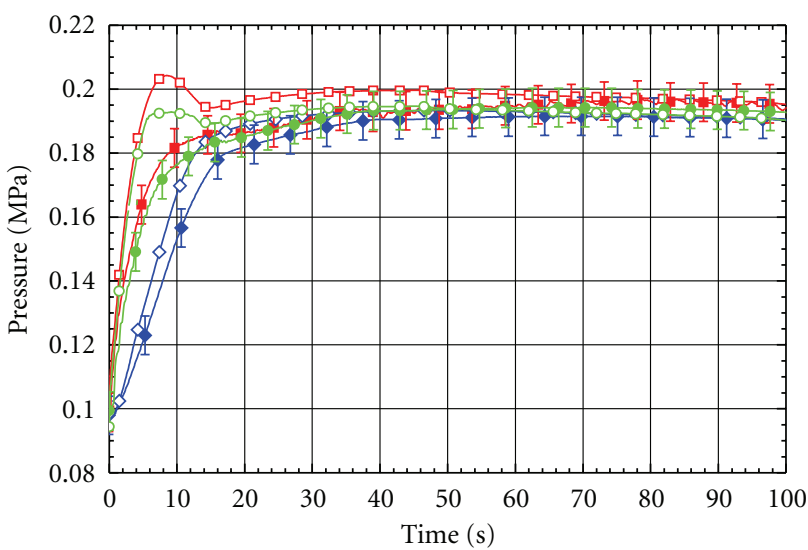

$$
\begin{array}{ll}
\rightarrow \text { SG box V1 (exp.) } & \multimap \text { SG box V1 (calc.) } \\
\rightarrow \text { BC gasroom V4 (exp.) } & \multimap-\text { BC gasroom V4 (calc.) } \\
\rightarrow-\text { Air trap V5 (exp.) } & \multimap
\end{array}
$$

(d)

FIGURE 11: Comparison of posttest calculation of Test 1 and NPP bandwidth. (a) C1 criterion; (b) C2 criterion; (c) C3 criterion; (d) experimental and calculated absolute pressure in SG box $V_{1}$, BC gasroom $V_{4}$, and air trap $V_{5}$.

\section{Analysis of BC Operation and Thermohydraulic Processes in Hermetic Compartments of Unit 3 of Kola NPP under LB LOCA with the COCOSYS Code}

For the analyses of the LB LOCA accident for the Kola NPP BC the input deck developed in [10] is used with some modifications. 46 zones, 62 atmospheric and 35 drain junctions, 2 pump systems, and 162 heat conducting structures of the Kola NPP, unit 3 were considered. The corresponding nodalization scheme is presented in Figure 14.

Table 9 lists the COCOSYS model zones (nodes), gives an explanation of the allocation of the zones to the NPP compartments, and includes the main characteristics of the zones. The steam generator box (compartment A201/1) is divided into two equal parts SGBOXA and SGBOXB. The break is assumed to occur in zone SGBOXB.

In the lower parts of the BCC compartments water can accumulate. Thus, they are modelled as separate sumps.

Special attention was paid to the modelling of the BC shaft (compartment A263/1). Inside this compartment the bubble condenser system is located. The system consists of twelve bubble condenser trays situated on separate floors spaced on various elevations of the BC shaft. For the purpose of obtaining the bandwidths of the inlet parameters for the different $\mathrm{BC}$ trays the bubble condenser shaft and the $\mathrm{BC}$ 


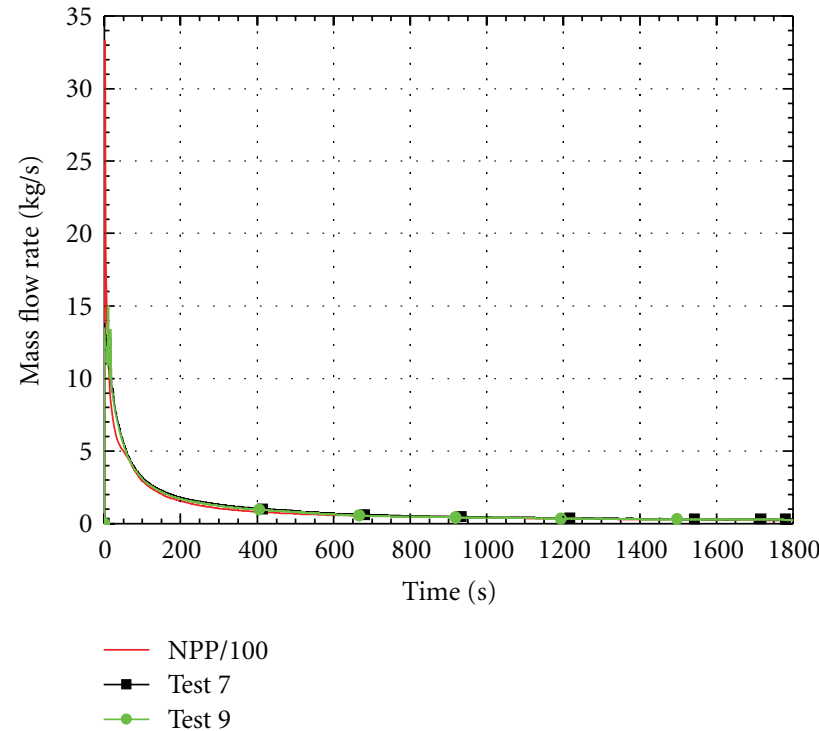

(a)

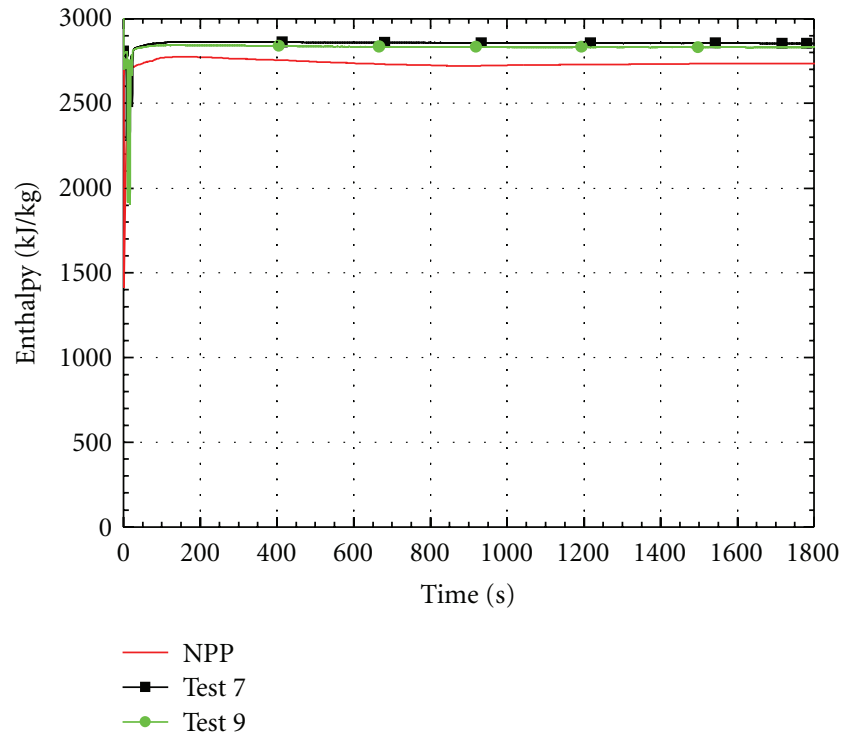

(b)

FIGURE 12: Comparison of experimental MERs with NPP scaled MER. Tests 7 and 9. (a) Break mass flow rate, (b) break enthalpy.

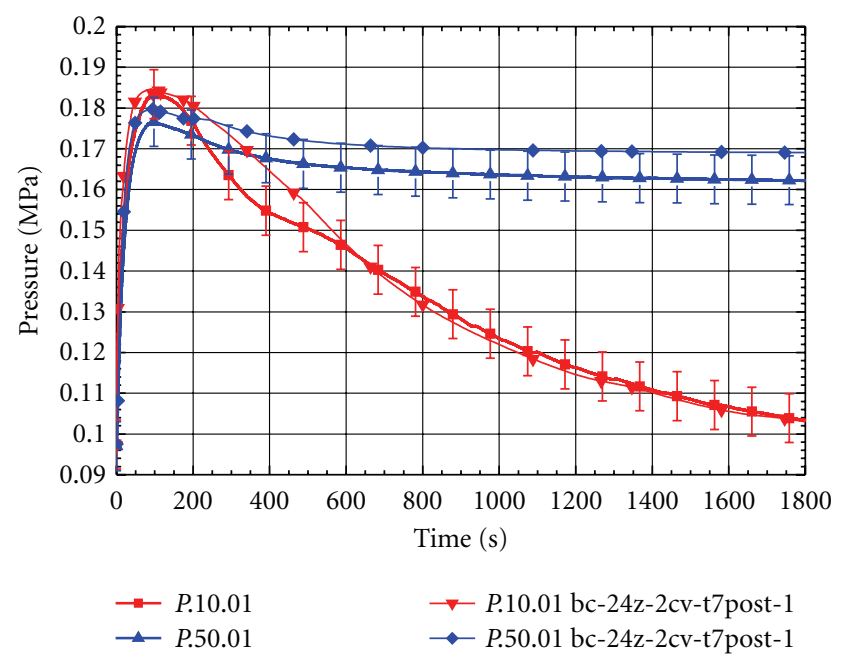

FIGURE 13: Measured and postcalculated absolute pressures in $V_{1}$ and $V_{5}$ boxes, Test 7 .

itself are divided into 21 parts with various volumes and elevations. The lowest and uppermost BC trays are modelled by separate zones.

Water carryover between the nodes is considered by values reducing downstream from the break location.

Zones are connected by atmospheric junctions (J1...J62) to simulate the transport of accident-generated 2-phase 2-component mixture. The gas volumes of the BC trays TRYA...TRYF are connected with the air traps ATRAPA. . .ATRAPF via the dynamic flaps J52. . .J57 to model the DN500 check valves including the inlet protection ducts. The DN250 relief valves are simulated by the dynamic flaps J46...J51. The flaps will be locked in closed position, if the pressure in $\mathrm{BC}$ shaft rises higher than $163,7 \mathrm{kPa}$.
This is controlled by the signals SIG250A...SIG250D. For calculations longer than investigated here, that is, longer than $40 \mathrm{~s}$, the unlocking pressure is of importance. It influences the occurrence of the reverse flow. Based on the experimental results, it was set to $190 \mathrm{kPa}$.

The BCC is assumed to be leak tight. Thus, there are no connections between compartment zones and zone ENVIRON which presents the environment.

There are 35 drain junctions in the Kola-3 NPP model. Drain junctions are assigned to simulate flow processes of water, for instance the drainage of injected water or condensate or the flow between different sumps to equalise the water surface levels.

The spray system, which injects water into SG boxes SGBOXA and SGBOXB, is simulated by two pump systems and emergency water storage tank TANKA. The operation of the pump systems is controlled by time- and processdependent valves.

Heat transfer and heat conduction processes are considered by so-called heat slabs. For each zone the relevant surfaces were defined as floor, side walls, and ceiling. The BC tray walls are subdivided into different heat slabs to consider that wall sides are linked with the pool (water), the gasroom or the gap/cap system.

In accordance with the results of COCOSYS posttest analysis of tests performed in BC V-213 test facility the developer version 2.0AA of the COCOSYS code was used for analysis of thermo-hydraulic processes in hermetic compartments of unit 3 of Kola NPP under LB LOCA, that is, the validated code was applied. In this version of COCOSYS the DRASYS zone model was improved to permit the simulation of humid air flowing from the $\mathrm{BC}$ water pool to the gasroom. Also for modelling of the water carryover into the gasroom and the air trap, special pumps were defined as for the analysis of the test facility. 
TABLE 8: Main experimental/calculated parameters characterizing loads on BC and boxes.

\begin{tabular}{|c|c|c|c|c|c|c|c|}
\hline \multirow{2}{*}{ No. } & \multirow{2}{*}{ Parameter } & \multicolumn{6}{|c|}{ Test $^{(\mathrm{a})}$} \\
\hline & & Test 4 & Test 5 & Test 1 & Test 7 & Test 9 & Test 12 \\
\hline \multirow{2}{*}{ (1) } & \multirow{2}{*}{$\begin{array}{l}\text { Maximum absolute pressurein box } V_{1} \text {, } \\
(\mathrm{MPa})\end{array}$} & 0.202 & 0.214 & 0.197 & 0.1835 & 0.175 & 0.111 \\
\hline & & 0.224 & 0.232 & 0.204 & 0.185 & 0.179 & 0.118 \\
\hline \multirow{2}{*}{ (2) } & \multirow{2}{*}{$\begin{array}{l}\text { Maximum absolute pressure in gasroom } \\
V_{4},(\mathrm{MPa})\end{array}$} & 0.191 & 0.199 & 0.194 & 0.177 & 0.169 & 0.107 \\
\hline & & 0.206 & 0.210 & 0.195 & 0.180 & 0.173 & 0.110 \\
\hline \multirow{2}{*}{ (3) } & \multirow{2}{*}{$\begin{array}{l}\text { Maximum absolute pressure in air trap } \\
V_{5},(\mathrm{MPa})\end{array}$} & 0.193 & 0.200 & 0.191 & 0.177 & 0.168 & 0.106 \\
\hline & & 0.191 & 0.196 & 0.193 & 0.180 & 0.174 & 0.113 \\
\hline \multirow{2}{*}{ (4) } & \multirow{2}{*}{$\begin{array}{l}\text { Maximum pressure difference across BC, } \\
(\mathrm{kPa})\end{array}$} & 14.55 & 15.73 & 11.62 & 7.8 & 7.7 & 4.9 \\
\hline & & 16.9 & 17.4 & 13.9 & $6.5^{(\mathrm{b})}$ & $6.7^{(\mathrm{b})}$ & 5.5 \\
\hline \multirow{2}{*}{ (5) } & \multirow{2}{*}{$\begin{array}{l}\text { Maximum pressure difference across } \\
\text { check valve, }(\mathrm{kPa})\end{array}$} & 50.6 & 54.3 & 37.8 & 13.6 & 10.9 & 1.3 \\
\hline & & 64.8 & 67.2 & 55.9 & 18.1 & 15.7 & 1.6 \\
\hline \multirow{2}{*}{ (6) } & \multirow{2}{*}{ Maximum temperature in box $V_{1},\left({ }^{\circ} \mathrm{C}\right)$} & 120 & 122 & 120 & 118 & 118 & 86 \\
\hline & & 124 & 125 & 121 & 172 & 181 & 101 \\
\hline \multirow{2}{*}{ (7) } & \multirow{2}{*}{$\begin{array}{l}\text { Maximum temperature of } \mathrm{BC} \text { water }{ }^{(\mathrm{c})} \text {, } \\
\left({ }^{\circ} \mathrm{C}\right)\end{array}$} & 78 & 78 & 60 & 56 & 63 & 38.5 \\
\hline & & 77 & 78 & 64 & 52 & 53 & 35 \\
\hline \multirow{2}{*}{ (8) } & \multirow{2}{*}{ Average temperature of $\mathrm{BC}$ water $(\mathrm{d}),\left({ }^{\circ} \mathrm{C}\right)$} & 61 & 59 & 45 & 48 & 52 & 36 \\
\hline & & 77 & 78 & 64 & 52 & 53 & 35 \\
\hline
\end{tabular}

${ }^{(a)}$ Experimental results are presented in upper part, calculation ones-in the lower part of table's cells;

(b) calculated values are the first peaks; due to COCOSYS model specifics only first pressure difference peak is reproduced in calculations;

(c) calculated values of maximum temperature are obtained at the end of calculation: for Test 4, Test 5, and Test 1 values are given at $100 \mathrm{~s}$, for Test 7 , Test 9 , and Test 12-at $1800 \mathrm{~s}$. Experimental values of maximum temperature are observed for Test 4 during interval $\sim 55-230 \mathrm{~s}$, for Test 5 during interval $\sim 45-85 \mathrm{~s}$, for Test 1 during interval $\sim 160-250 \mathrm{~s}$, for Test 7 during interval $\sim 800-1800 \mathrm{~s}$, for Test 9 during interval $\sim 1100-1800 \mathrm{~s}$, and for Test 12 during interval $\sim 2700-$ $5000 \mathrm{~s}$

(d) for Test 4, Test 5, and Test 1 values are given at $100 \mathrm{~s}$, for Test 7, Test 9, and Test 12-at $1800 \mathrm{~s}$. Calculated maximum and average temperatures of BC water are equal to each other due to using of only one node for $\mathrm{BC}$ pool in calculation.

The full-scale NPP MER (coolant mass flow rate and specific enthalpy as calculated with ATHLET) is used for COCOSYS analysis as boundary condition. tion.

The following initial conditions are used in the calcula-

Air temperatures in the hermetic compartments are

(i) $50^{\circ} \mathrm{C}$-in all compartments before shaft;

(ii) $35^{\circ} \mathrm{C}$-in the shaft;

(iii) $30^{\circ} \mathrm{C}$-in the air traps.

Water temperature in $\mathrm{BC}$ trays is $35^{\circ} \mathrm{C}$.

Humidity in the hermetic compartments is

(i) 60\%-in all compartments before the BC shaft;

(ii) $90 \%$-in the BC shaft;

(iii) $20 \%$-in the air traps.

Water carryover factor (COCOSYS model parameter) is

(i) 0.4 -in the break node;

(ii) 0.2 - in the nodes adjacent to the break node;

(iii) 0.1 -in the other nodes.

In Figure 15(a) the calculated pressure behavior in the break node is presented. For the NPP the maximum pressure $\sim 184 \mathrm{kPa}$ is achieved at $3.8 \mathrm{~s}$, whereas the maxima in Test 1 were $204 \mathrm{kPa}$ after $8,5 \mathrm{~s}$ (calculated) and $197 \mathrm{kPa}$ after $78 \mathrm{~s}$ (measured) as shown in Figure 11(d). The reasons for the deviation from the NPP value is explained above in chapter 5 (Tests 1,4 , and 5 ).

The temperature history in the break node is shown on the Figure $15(\mathrm{~b})$. The maximum value is about $118^{\circ} \mathrm{C}$.

The pressure difference over gap/cap systems in the short time phase is illustrated on Figure 15(c). The highest pressure differences occur in the upper trays $(\sim 26 \mathrm{kPa})$, lower trays are effected by a maximum pressure difference of about $17 \mathrm{kPa}$. However, as it is shown in chapter 5 lumpedparameter containment codes like CONTAIN, TRACO, VSPLESK, or COCOSYS overpredict the values of the BC pressure difference [18]. One reason for that was identified to be the neglection of elastic compression of the $\mathrm{BC}$ walls. Another reason was the occurrence of counter-current flow in the channel connecting $V_{2}$ and $V_{3}$, which was not considered also.

The $\mathrm{BC}$ water temperature is shown on Figure 15(d). The maximum value $\left(\sim 59^{\circ} \mathrm{C}\right)$ is achieved in TRYA (1st tray). This value is still relatively far below the saturation temperature, knowing that BC-related posttest calculations with different codes showed a strong overestimation of the water heatup in LB LOCA cases. 
TABLE 9: List and characteristics of the Kola-3 BCC zones.

\begin{tabular}{|c|c|c|c|c|c|c|}
\hline Node & Kola NPP compartment & Node type & Volume, $\mathrm{m}^{3}$ & Centre elevat. $\mathrm{m}$ & Floor area $\mathrm{m}^{2}$ & Floor elevat. $\mathrm{m}$ \\
\hline SGBOXA & SG box A201/1; left half & $\mathrm{E}^{(1)}$ & 2601.73 & 12.57 & 520.0 & 7.74 \\
\hline SUMPA & SG box A201/1; lower part & $\mathrm{NE}$ & 750.0 & 7.02 & 520.0 & 6.30 \\
\hline SGBOXB & SG box A201/1; right half & $\mathrm{E}$ & 2594.43 & 12.57 & 520.0 & 7.74 \\
\hline SUMPB & SG box A201/1; lower part & $\mathrm{NE}$ & 750.0 & 7.02 & 520.0 & 6.30 \\
\hline МСРВОХ & $\begin{array}{l}\text { MCP electric motors } \\
\text { compartment A301/1 }\end{array}$ & $\mathrm{E}$ & 2186.24 & 13.98 & 348.0 & 10.567 \\
\hline ISOLA & $\begin{array}{l}\text { Corridor of penetrations with } \\
\text { ECCS isolation valves A202/1 }\end{array}$ & $\mathrm{E}$ & 1578.35 & 11.86 & 327.76 & 6.32 \\
\hline ISOLB & $\begin{array}{l}\text { Corridor of penetrations with } \\
\text { ECCS isolation valves A203/1 }\end{array}$ & $\mathrm{E}$ & 1731.4 & 11.86 & 350.96 & 6.32 \\
\hline CAVTY & $\begin{array}{l}\text { Reactor cavity (below the } \\
\text { support ring) A004/1 }\end{array}$ & $\mathrm{E}$ & 290.73 & 8.10 & 36.32 & -6.10 \\
\hline ACCUMA & HA compartment A525/1 & $\mathrm{E}$ & 372.96 & 21.95 & 29.70 & 18.90 \\
\hline ACCUMB & HA compartment A526/1 & $\mathrm{E}$ & 372.96 & 21.95 & 29.70 & 18.90 \\
\hline VALVC & Valves chamber A306/1 & $\mathrm{E}$ & 100.92 & 12.05 & 34.80 & 10.60 \\
\hline PRESR & Pressurizer box A527/1 & $\mathrm{E}$ & 357.02 & 21.95 & 52.45 & 18.90 \\
\hline VALVSG & $\begin{array}{l}\text { Chamber of SG box valves } \\
\text { A211/1 }\end{array}$ & $\mathrm{E}$ & 567.2 & 12.18 & 107.44 & 6.26 \\
\hline FILTRI & $\begin{array}{l}\text { Compartment for filters of } \\
\text { installation I A302/1 }\end{array}$ & $\mathrm{E}$ & 105.94 & 14.0 & 15.60 & 10.60 \\
\hline CORRDA & $\begin{array}{l}\text { Transition room between SG box } \\
\text { and BC shaft A } 265 / 1\end{array}$ & $\mathrm{E}$ & 602.18 & 9.85 & 93.23 & 6.60 \\
\hline CORRDB & $\begin{array}{l}\text { Transition room between SG box } \\
\text { and BC shaft A266/1 }\end{array}$ & $\mathrm{E}$ & 602.18 & 9.85 & 92.73 & 6.60 \\
\hline VENTC & $\begin{array}{l}\text { HVAC systems machine hall } \\
\text { A00032/1 }\end{array}$ & $\mathrm{E}$ & 4722.14 & -0.75 & 655.84 & -6.50 \\
\hline SHFRA & $\begin{array}{l}\text { Bubble condenser shaft A263/1; } \\
\text { front part }\end{array}$ & $\mathrm{E}$ & 491.38 & 12.76 & 52.0 & 8.04 \\
\hline SHFRB & $\begin{array}{l}\text { Bubble condenser shaft A263/1; } \\
\text { front part }\end{array}$ & $\mathrm{E}$ & 412.5 & 22.54 & 40.8 & 17.49 \\
\hline SHFRC & $\begin{array}{l}\text { Bubble condenser shaft A263/1; } \\
\text { front part }\end{array}$ & $\mathrm{E}$ & 412.5 & 32.65 & 40.8 & 27.60 \\
\hline SHFRD & $\begin{array}{l}\text { Bubble condenser shaft A263/1; } \\
\text { front part }\end{array}$ & E & 453.3 & 43.26 & 40.8 & 37.71 \\
\hline SHLTA & $\begin{array}{l}\text { Bubble condenser shaft A263/1; } \\
\text { lateral part }\end{array}$ & $\mathrm{E}$ & 561.64 & 12.76 & 58.35 & 8.04 \\
\hline SHLTB & $\begin{array}{l}\text { Bubble condenser shaft A263/1; } \\
\text { lateral part }\end{array}$ & $\mathrm{E}$ & 589.9 & 22.54 & 58.35 & 17.49 \\
\hline SHLTC & $\begin{array}{l}\text { Bubble condenser shaft A263/1; } \\
\text { lateral part }\end{array}$ & $\mathrm{E}$ & 589.9 & 32.65 & 58.35 & 27.56 \\
\hline SHLTD & $\begin{array}{l}\text { Bubble condenser shaft A263/1; } \\
\text { lateral part }\end{array}$ & $\mathrm{E}$ & 723.0 & 43.26 & 58.35 & 37.71 \\
\hline BTWTRA & $\begin{array}{l}\text { Bubble condenser shaft A263/1, } \\
\text { volume below BC trays }\end{array}$ & $\mathrm{E}$ & 131.0 & 7.84 & 218.6 & 7.19 \\
\hline BTWTRB & $\begin{array}{l}\text { Bubble condenser shaft A263/1, } \\
\text { volume below BC trays }\end{array}$ & $\mathrm{E}$ & 262.0 & 12.29 & 437.2 & 10.39 \\
\hline BTWTRC & $\begin{array}{l}\text { Bubble condenser shaft A263/1, } \\
\text { volume below BC trays }\end{array}$ & $\mathrm{E}$ & 414.0 & 21.16 & 689.4 & 17.49 \\
\hline BTWTRD & $\begin{array}{l}\text { Bubble condenser shaft A263/1, } \\
\text { volume below BC trays }\end{array}$ & $\mathrm{E}$ & 414.0 & 31.27 & 689.4 & 27.60 \\
\hline BTWTRE & $\begin{array}{l}\text { Bubble condenser shaft A263/1, } \\
\text { volume below BC trays }\end{array}$ & $\mathrm{E}$ & 276.0 & 39.69 & 459.6 & 37.71 \\
\hline BTWTRF & $\begin{array}{l}\text { Bubble condenser shaft A263/1, } \\
\text { volume below BC trays }\end{array}$ & $\mathrm{E}$ & 130.0 & 44.745 & 216.3 & 44.45 \\
\hline
\end{tabular}


TABle 9: Continued.

\begin{tabular}{|c|c|c|c|c|c|c|}
\hline Node & Kola NPP compartment & Node type & Volume, $\mathrm{m}^{3}$ & Centre elevat. $\mathrm{m}$ & Floor area $\mathrm{m}^{2}$ & Floor elevat. $\mathrm{m}$ \\
\hline SUMPC & $\begin{array}{l}\text { Bubble condenser shaft A263/1; } \\
\text { lower part }\end{array}$ & $\mathrm{NE}$ & 303.2 & 7.36 & 110.35 & 6.68 \\
\hline TRYA $^{(2)}$ & Bubble condenser tray; 1st floor & $\mathrm{D}$ & 565.386 & 9.34 & 208.78 & 7.79 \\
\hline TRYB & $\begin{array}{l}\text { Bubble condenser trays; 2nd, 3rd } \\
\text { floors }\end{array}$ & $\mathrm{D}$ & 1130.772 & 13.89 & 417.56 & 10.99 \\
\hline TRYC & $\begin{array}{l}\text { Bubble condenser trays; } 4 \text { th, } 5 \text { th, } \\
\text { 6th floors }\end{array}$ & $\mathrm{D}$ & 1898.869 & 22.85 & 656.37 & 18.09 \\
\hline TRYD & $\begin{array}{l}\text { Bubble condenser trays; } 7 \text { th, } 8 \text { th, } \\
\text { 9th floors }\end{array}$ & $\mathrm{D}$ & 1898.869 & 32.96 & 656.37 & 28.20 \\
\hline TRYE & $\begin{array}{l}\text { Bubble condenser trays; 10th, } \\
11 \text { th floors }\end{array}$ & $\mathrm{D}$ & 1265.946 & 41.38 & 437.58 & 38.31 \\
\hline TRYF & Bubble condenser tray; 12 th floor & $\mathrm{D}$ & 815.222 & 46.44 & 203.06 & 45.05 \\
\hline ATRAPA & $\begin{array}{l}\text { Air trap compartment A264/1; } \\
\text { lower part }\end{array}$ & $\mathrm{E}$ & 1386.17 & 8.65 & 446.55 & 7.0975 \\
\hline ATRAPB & $\begin{array}{l}\text { Air trap compartment A264/1; } \\
\text { upper part }\end{array}$ & $\mathrm{E}$ & 2772.33 & 13.31 & 446.55 & 10.20 \\
\hline ATRAPC & Air trap compartment A423/1 & $\mathrm{E}$ & 4014.48 & 22.03 & 446.55 & 17.53 \\
\hline ATRAPD & Air trap compartment A530/1 & $\mathrm{E}$ & 4014.48 & 32.14 & 446.55 & 27.64 \\
\hline ATRAPE & $\begin{array}{l}\text { Air trap compartment A635/1; } \\
\text { lower part }\end{array}$ & $\mathrm{E}$ & 3230.05 & 41.37 & 446.55 & 37.75 \\
\hline ATRAPF & $\begin{array}{l}\text { Air trap compartment A635/1; } \\
\text { upper part }\end{array}$ & $\mathrm{E}$ & 1615.02 & 46.79 & 446.55 & 44.98 \\
\hline TANKA & ECCS tanks ${ }^{(3)}$ & $\mathrm{E}$ & 1000.0 & 1.94 & 257.14 & 0.00 \\
\hline ENVIRON & Environment & $\mathrm{E}$ & $1 \times 10^{6}$ & 2.50 & $1 \times 10^{4}$ & 0.00 \\
\hline
\end{tabular}

(1) "E": equilibrium zone model, "NE": nonequilibrium zone model, "D": PSS zone model DRASYS according to COCOSYS concept [7].

${ }^{(2)}$ Total volume of D-type node includes both gas and water ones.

${ }^{(3)}$ Comprising several tanks (introduced for correct water mass balance).

\section{Conclusion}

In the framework of the Tacis Project R2.01/99 EREC has performed six tests according to the PH2.13./95 Project test matrix:

(i) three LB LOCA tests (Tests 1, 4, and 5 according to the test matrix);

(ii) two MSLB tests (Tests 7 and 9);

(iii) one SB LOCA test (Test 12).

The appropriate test scenarios for BC V-213 test facility, modeling accidents in the Kola NPP unit 3, were determined with pretest calculations performed with the ATHLET code. The analysis of the test results has shown that calculated initial conditions and test scenarios were properly reproduced in the tests. The tests were performed successfully and are of high importance with regard to the assessment of the functioning of the Bubble Condenser with specific Kola-3 NPP features under accident conditions. They are also very important for code validation purpose.

The main aim of the posttest analysis of the tests performed at BC V-213 test facility is to validate the COCOSYS code for calculating the thermo-hydraulic processes in the hermetic compartments and BC. BC loadings and pressure increase in the compartments are mainly determined by mass and energy release rate (MER) of the coolant discharged through the break. The measurement of the mass flow rate of discharged coolant with VTI tube is valid only during the first seconds, when discharge of subcooled water takes place. Mass flow rate of the two-phase mixture is not measured correctly by this gauge, because density of two-phase mixture (parameter required for determination of the mass flow rate) is not measured at the test facility. So, MER can be determined by posttest analysis with best estimate thermalhydraulic code, for example, ATHLET code. If ATHLET results agree well with other important experimental data (pressure, temperature, collapsed level, and mass flow rate of single-phase coolant), it is possible to conclude that ATHLET provides reliable MER as for single-phase and two-phase regions.

Results of ATHLET Posttest Analysis. In general, results of ATHLET calculations agree well with experimental data (pressure, temperature, collapsed level, and mass flow rate of single-phase coolant) for all tests. Performed sensitivity study permitted to determine optimal model parameters and to reach good agreement with experimental data. So, it can be concluded that ATHLET has provided reliable MER both for single-phase and two-phase regions, which can be used as boundary condition for subsequent COCOSYS 


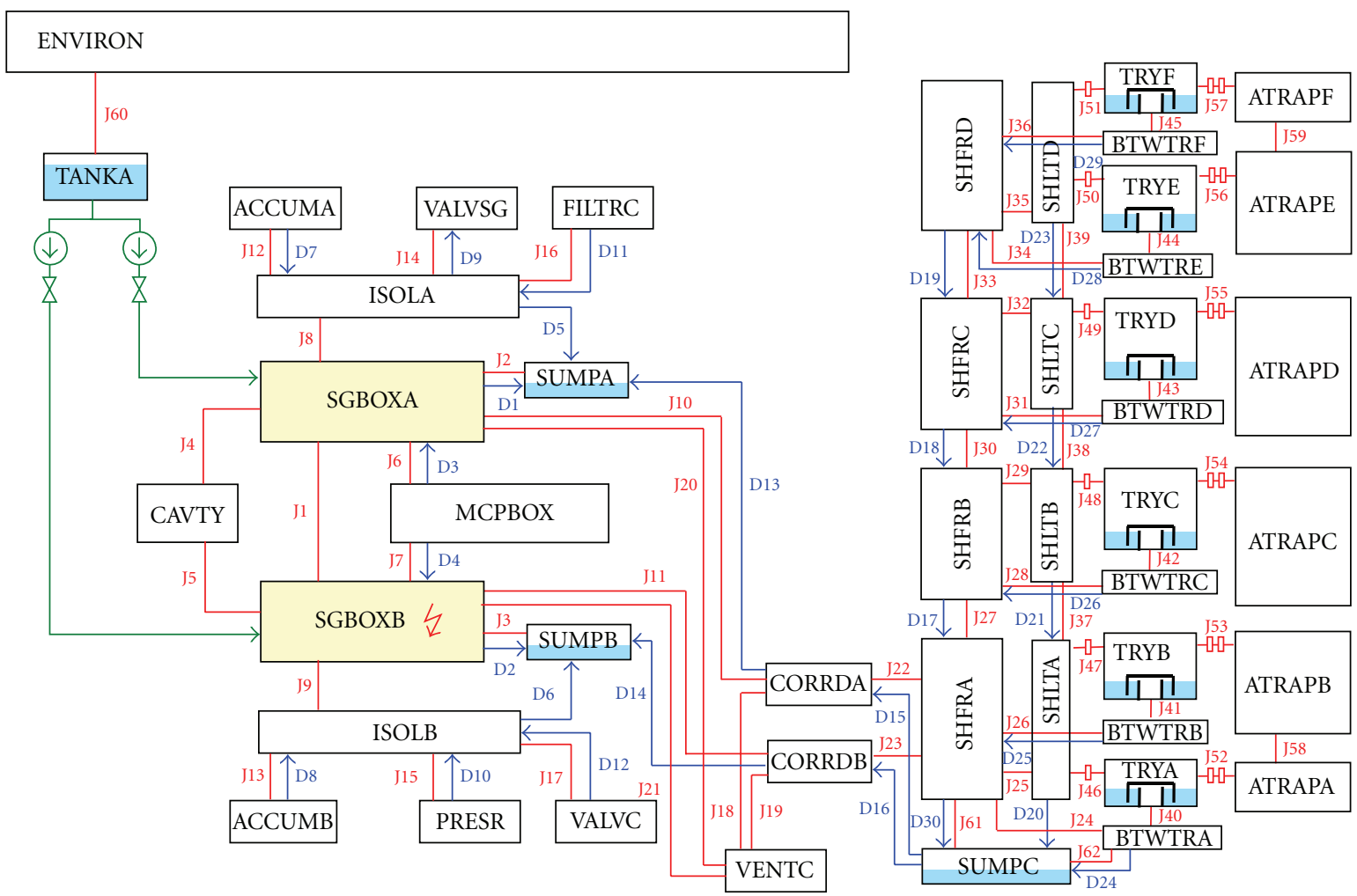

Figure 14: Nodalization scheme of Kola NPP unit 3 Bubble Condenser Containment.

(or other containment code) calculations of thermal-hydraulic processes in the hermetic compartments and BC.

LB LOCA Tests. Test 4 (LB LOCA) was analyzed with the COCOSYS code in detail. Many variant calculations were performed to adequately reproduce the behavior of measured parameters. Other tests were analyzed with model parameters determined for Test 4 .

The results of the sensitivity study with the COCOSYS code using experimental data led to certain model changes, which is a further step of code validation. In general, satisfied agreement between calculated and experimental data is obtained.

Calculations revealed that the main problem for $\mathrm{LB}$ LOCA tests is an overestimation of BC pool water heatup with the COCOSYS code. Similar results were obtained with other containment codes as CONTAIN, TRACO, and VSPLESK [18]. The predicted heatup of BC pool water is approximately twice greater than the experimental one. Furthermore, it can be concluded that the overestimation of the pool water heatup is accident dependent and much larger for LB LOCA tests.

Possible reasons for such overestimation are the following:

(1) steam condensation before BC module is not adequately described by the code (nonrealistic value of heat transfer coefficient or occurrence of any peculiarities of heat structures which are not taken into account e.g., exact simulation of wooden insulation);

(2) strong nonuniform distribution of water temperature observed in the test (difficulties with correct definition of average BC water temperature, possible steam breakthrough in the most loaded parts);

(3) occurrence of counter-current flows between $V_{0}$ dead-end volume and break node and/or $V_{2}$ and break node, which cannot be reproduced by calculations with lumped-parameter codes.

Comparison of experimental and calculated pressure differences across $\mathrm{BC}$ walls shows that predicted maximum value of the pressure difference is higher than experimental value for all tests (exp./calc. pressure difference: Test $4-14.55 \mathrm{kPa} / 16.9 \mathrm{kPa}$, Test $5-15.73 \mathrm{kPa} / 17.4 \mathrm{kPa}$, Test $1-$ $11.62 \mathrm{kPa} / 13.9 \mathrm{kPa})$. Reasonable explanation of it is an elastic deformation of the $\mathrm{BC}$ steel walls, not considered in the COCOSYS code. A second reason might be the blocking of the left channel by the counter-current flow revealed in the test and not simulated in the calculation.

Another important finding of posttest analysis is the influence of the opening of the DN250 relief valve on the occurrence of the reverse water flow. The reverse water flow from the $\mathrm{BC}$ trays into the $\mathrm{BC}$ shaft is caused by reverse pressure difference; when the pressure in the $\mathrm{BC}$ gasroom (above water seal) becomes higher than the pressure in the BC shaft, DN250 relief valve connecting BC gasroom and $\mathrm{BC}$ shaft should be locked for occurrence of the reverse 


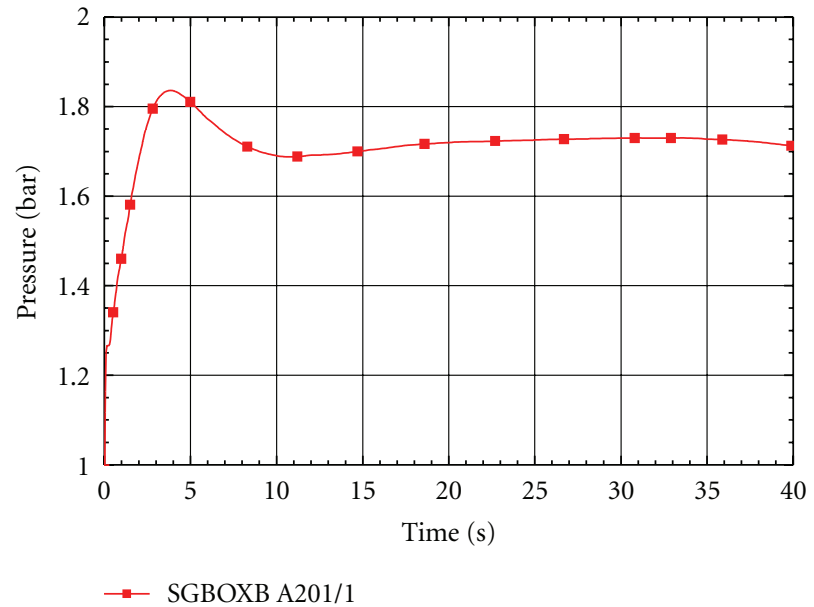

(a)

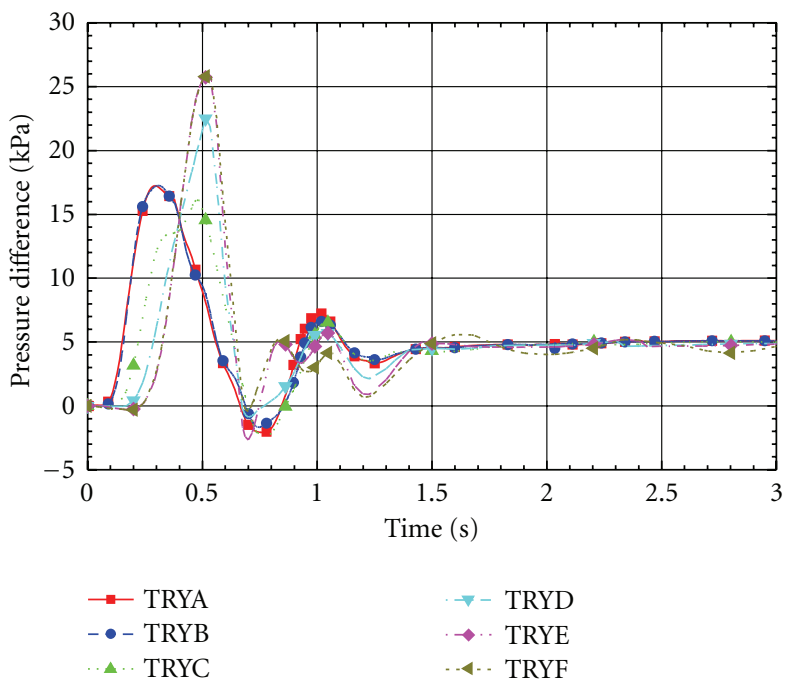

(c)

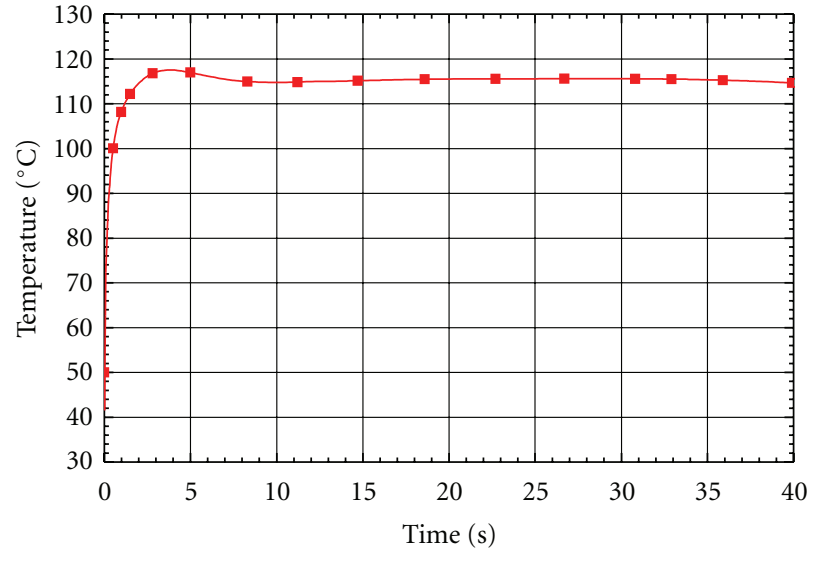

$\rightarrow$ SGBOXB A201/1

(b)

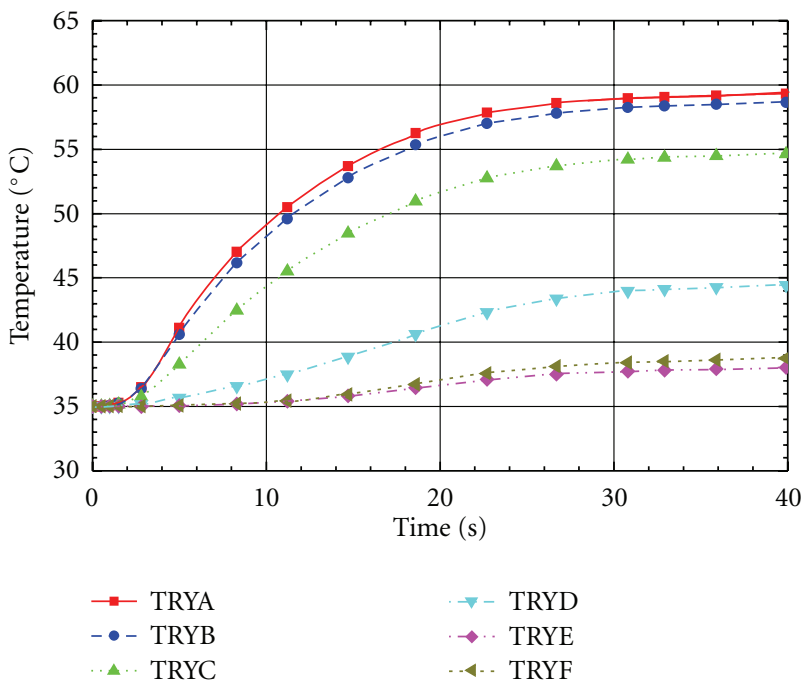

(d)

FIGURE 15: Calculation of LB LOCA at unit 3 of Kola NPP with the COCOSYS code. (a) Pressure history in the break node A201/1; (b) temperature in the break node A201/1; (c) pressure difference across the BC wall; (d) BC water temperature.

flow. So, locking/unlocking pressure value of DN250 relief valve influences the occurrence of the reverse flow. The special gauge for DN250 cover opening permits to determine moment of valve opening and corresponding value of the pressure in the shaft. In the tests it was revealed that the relief valve opened at a pressure in $\mathrm{BC}$ shaft exceeding the design unlocking value. This is caused by the heatup of the valves bellow (causing a pressure increase in the bellow), which is accident dependent also. Using a nonrealistic value for the unlocking pressure can prevent the reverse flow, so in the posttest calculations the experimental values of unlocking pressures were used. It permitted to calculate reverse flow in Test 5.

MSLB Tests. They are rather well simulated by the COCOSYS code. Calculated pressure and temperature in the boxes are in good coincidence with experimental values. The water heatup is overpredicted by the code, but not as strong as in the previous LB LOCA tests (the relative difference is reduced 10 times).

Predicted values of the first peak of pressure difference across BC walls for MSLB tests coincide with experimental values rather well. However, it is necessary to note that in the experiment maximum values of the pressure difference across BC walls were achieved during the second peak. Due to the model specifics used in COCOSYS, only first pressure difference peak is reproduced in the calculations.

SB LOCA Tests. Posttest analysis of thermal-hydraulic processes in the boxes and $\mathrm{BC}$ has shown that loads on $\mathrm{BC}$ and hermetic compartments are practically negligible under SB LOCA conditions. The deviations of calculated and measured parameters are in the order of the gauge uncertainty (pressure) or less (temperature).

The main idea of the SB LOCA test performance was to investigate experimentally whether the gap/cap systems tend 
to condensation oscillations under SB LOCA conditions. Main outcome of this test is that no condensation oscillations of the BC pool water were observed.

Evaluation of the results of posttest analysis with regard to the safety relevance was implemented comparing main thermal-hydraulic parameters characterizing loads on BC and hermetic compartments. LB LOCA conditions have a higher degree of safety relevance compared with MSLB and especially SB LOCA.

COCOSYS Analysis of Kola-3. The COCOSYS code was exemplarily used in NPP calculations for Kola-3. The findings revealed during posttest analysis of the tests performed at the BC V-213 test facility were taken into account for the development of the COCOSYS model of unit 3 of Kola NPP. The main results of calculation are maximum pressure$184 \mathrm{kPa}$, maximum temperature $-118^{\circ} \mathrm{C}$, and $\mathrm{BC}$ pool water temperature $-59^{\circ} \mathrm{C}$. These values are below design limits. However, it should be noted that a consequence of the Kola NPP configuration (twice number of check valves,...) is a pressure level more close to the design value compared to the other NPPs with VVER 440/V-213.

Finally, results of the experimental campaign carried out under the Tacis R2.01/99 Project [19] confirmed the Bubble Condenser functionality during large and small break LOCAs and MSLB accidents in Kola-3 NPP. Maximum loads were reached in the LB LOCA case. No condensation oscillations were observed.

\section{Nomenclature}

ATHLET: Bestestimate thermal-hydraulic code for the reactor circuit

BC: $\quad$ Bubble condenser

BCC: Bubble Condenser Containment

COCOSYS: Containment thermohydraulic code

EREC: Electrogorsk Research and Engineering Centre on NPPs safety

GRS: Gesellschaft für Anlagen- und Reaktorsicherheit

HS: $\quad$ Heat structures

LB LOCA: Large break loss-of-coolant accident

LOCA: Loss-of-coolant accident

MER: $\quad$ Mass and energy release rate

MSLB: $\quad$ Main steam line break

NPP: $\quad$ Nuclear power plant

SB LOCA: Small break loss-of-coolant-accident

SG: $\quad$ Steam generator

VVER: Pressurized water reactor (Russian type).

\section{Acknowledgment}

The major part of the work described in this paper was supported by the Tacis Project "Experimental Studies on (a) Bubble Condenser Test Facility (R2.01/99). (b) TKR Test Facility (R2.02/99) at EREC-Electrogorsk."

\section{References}

[1] A. M. Bukrinsky, Y. V. Rzheznikov, Y. V. Shvyryaev et al., "Accident Localization System under LB LOCA conditions at NPP with VVER-440," Thermal Engineering, no. 4, pp. 47-49, 1978.

[2] "Bubble condenser experimental qualification (PH 2.13/95)," Final Thermal-Hydraulic Test Report BC-D-ER-SI-0028, Rev. 0. Task 2: Deliverable 2.4, 1999.

[3] "Experimental Studies on: A. Bubble Condenser Test Facility (R2.01/99). B. TKR Test Facility (R2.02/99) at EREC-Electrogorsk, Re-mobilization of the $\mathrm{BC}$ V-213 test facility and result of comparative experiment," Tech. Rep. BC-TR-01E, 2003.

[4] "Experimental studies on: A. Bubble condenser test facility (r2.01/99). b. TKR test facility (r2.02/99) at EREC-Electrogorsk. modification of the test facility for the Kola NPP tests," Tech. Rep. BC-TR-02E, 2003.

[5] "Bubble condenser experimental qualification (PH 2.13/95)," Test Matrix Development BC-D-ER-SI-0006, Rev. 5. Deliverable 2.2, Part 2 of 6, 1999.

[6] ATHLET Mod 1.2 Cycle D, “User's Manual, GRS-P-1/1,” September 2001.

[7] COCOSYS V1.2, “User Manual, GRS-P-3/1,” July 2000.

[8] H. Wolff et al., "Pre-and post-test calculations of the EREC experiment SLB G02 Project INT 9142, Task 3.1,” Tech. Rep. GRS-V-INT 9142-6/2003, Berlin, Germany, 2003.

[9] “Input Data Base for WWER 440/W213 Systems," Tech. Rep. RF13-TR02, 2000.

[10] “Experimental,” Tech. Rep. BC-TR-03E, 2003.

[11] "Experimental studies on: a. Bubble condenser test facility (R2.01/99). B. TKR test facility (R2.02/99) at EREC-Electrogorsk. Test plan and pre-test calculations," Tech. Rep. BC-TR04E, 2003.

[12] "Experimental studies on: a. Bubble condenser test facility (R2.01/99). B. TKR test facility (R2.02/99) at ERECElectrogorsk. Results of LB LOCA test 5," type BC-TR-05E, 2003.

[13] "Experimental studies on: a. Bubble condenser test facility (R2.01/99). B. TKR test facility (R2.02/99) at EREC-Electrogorsk. Results of LB LOCA test 1," Tech. Rep. BC-TR-06E, 2003.

[14] "Experimental studies on: a. Bubble condenser test facility (R2.01/99). B. TKR test facility (R2.02/99) at EREC-Electrogorsk. Results of MSLB test 7," type BC-TR-07E, 2003.

[15] "Experimental studies on: a. Bubble condenser test facility (R2.01/99). B. TKR test facility (R2.02/99) at EREC-Electrogorsk. Results of MSLB test 9," Tech. Rep. BC-TR-08E, 2003.

[16] "Experimental studies on: a. Bubble condenser test facility (R2.01/99). B. TKR test facility (R2.02/99) at EREC-Electrogorsk. Results of SB LOCA test 12," Tech. Rep. BC-TR-09E, 2003.

[17] I. E. Idel'chik, Handbook on Hydraulic Resistances, Moscow, Russia, 1992.

[18] "Answers to remaining questions on Bubbler Condenser," Activity Report of the OECD NEA Bubbler-Condenser Steering Group NEA/CSNI/R, 2003.

[19] "Experimental studies on: a. Bubble condenser test facility (R2.01/99). B. TKR test facility (R2.02/99) at EREC-Electrogorsk," Tech. Rep., 2005. 

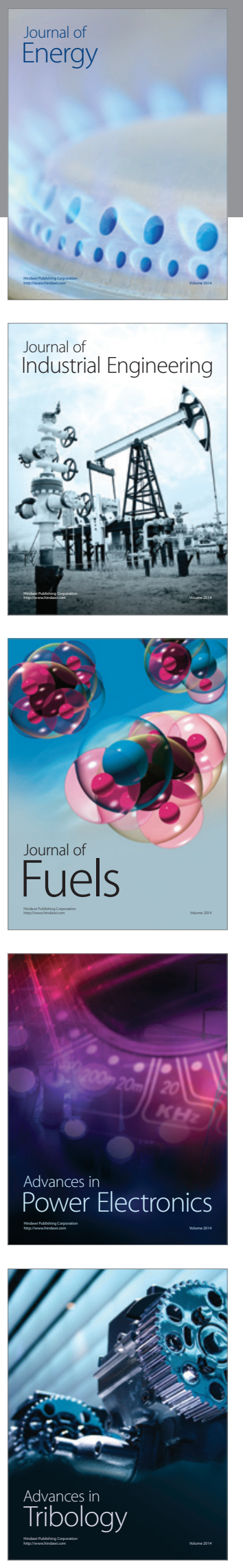
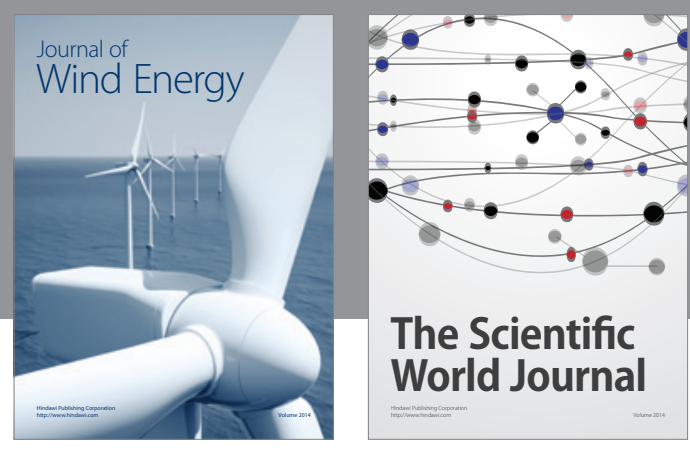

The Scientific World Journal

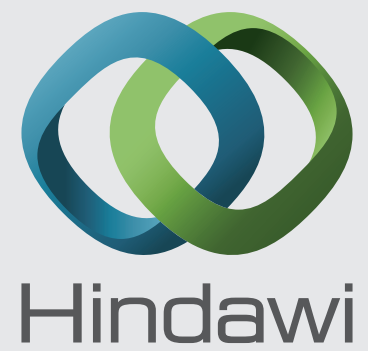

Submit your manuscripts at http://www.hindawi.com
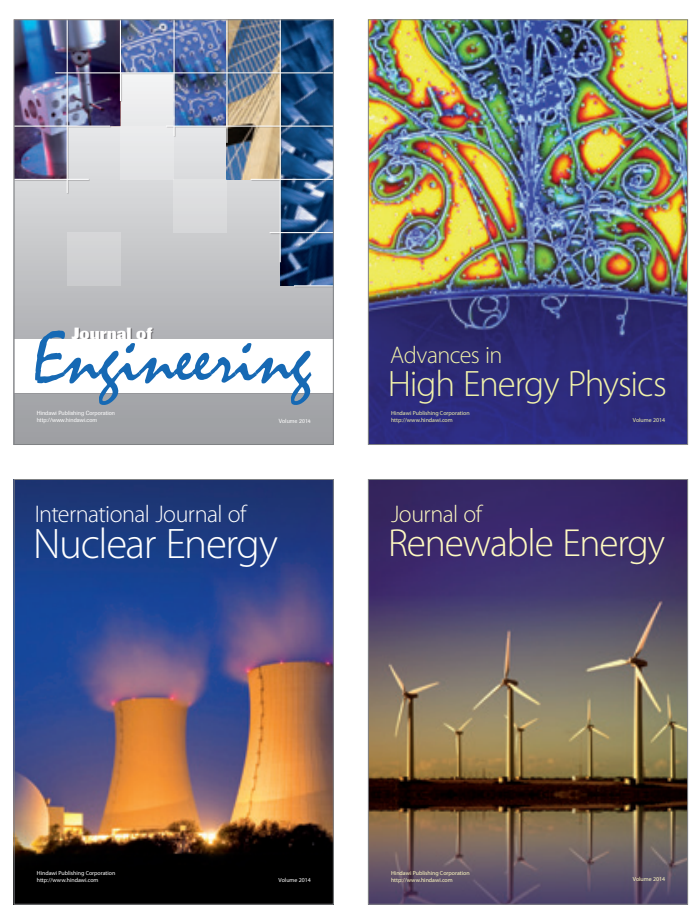

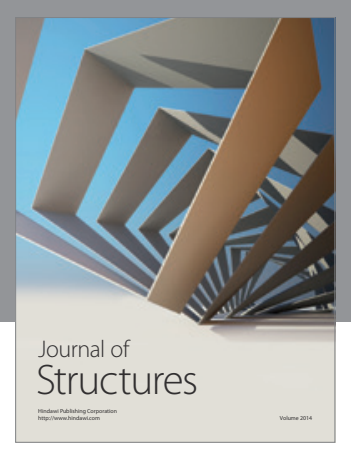

Rotating
Mechinery
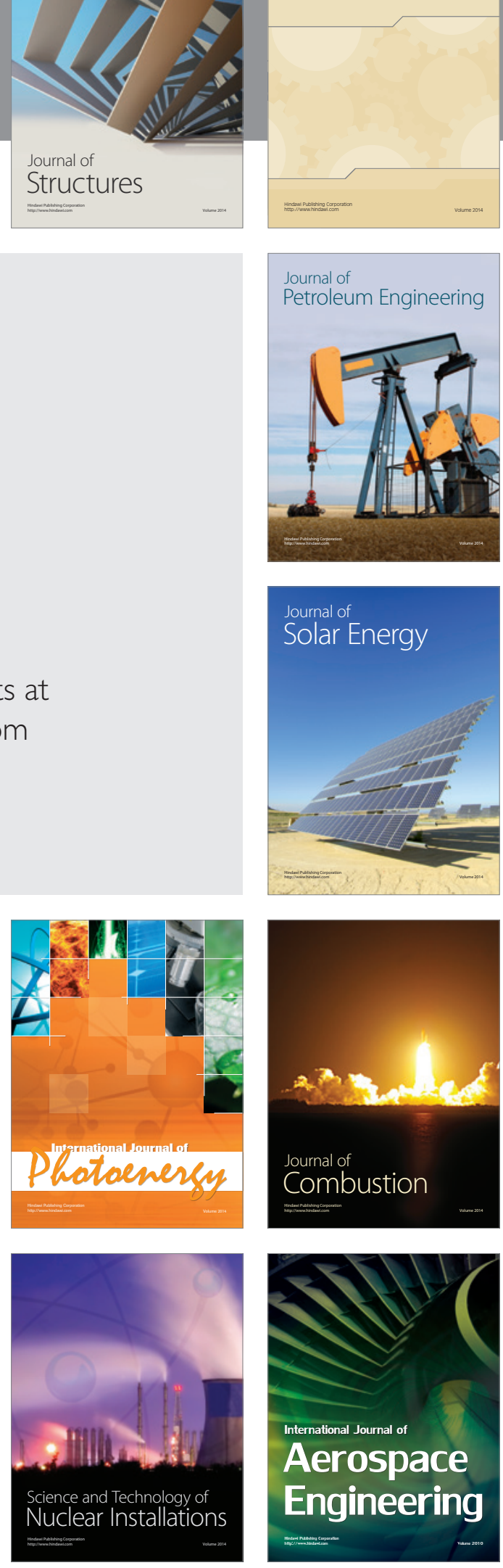